\title{
Recent Research on Bioactive Xanthones from Natural Medicine: Garcinia hanburyi
}

\author{
Buyun Jia, ${ }^{1}$ Shanshan Li, ${ }^{1}$ Xuerui Hu, ${ }^{1}$ Guangyu Zhu, ${ }^{1,2}$ and Weidong Chen ${ }^{1,3}$
}

Received 4 March 2015; accepted 18 May 2015; published online 8 July 2015

\begin{abstract}
Garcinia hanburyi, a tropical plant found in south Asia, has a special long history in the development of both medicine and art. This review mainly focuses on the pharmacy research of the bioactive compounds from the plant in recent years. Preparative and analysis separation methods were introduced. Moreover, the chemical structure of the isolated compounds was included. The studies of biological activities of the caged xanthones from the plant, including antitumor, anti-HIV-1, antibacterial, and neurotrophic activities, were reviewed in detail. Furthermore, the mechanisms of its antitumor activity were also reviewed. As mentioned above, some of the xanthones from G. hanburyi can be promising drug candidates, which is worth studying. However, we still need much evidence to prove their efficacy and safety. So, further research is critical for the future application of xanthones from G. hanburyi.
\end{abstract}

KEYWORDS: bioactive; Garcinia hanburyi; xanthones.

\section{INTRODUCTION}

Garcinia hanburyi, whose resin named gamboge is originally used as pigment and folk medicine, was found in the tropical rainforest of Thailand, southern China, Cambodia, and part of Malaysia. As a matter of fact, gamboge, a goldcolored resin, has a long and rich history in both the sciences and the arts. In recent years, a special group of xanthones, caged Garcinia xanthones, which have been identified as bioactive compounds with potent biological activities such as antitumor, anti-HIV-1, antibacterial, and anti-inflammatory, is naturally found from the resin, fruit, and other parts of the plant. The unique 4-oxa-tricyclo $\left(4 \cdot 3 \cdot 1.0^{3,7}\right) \mathrm{dec}-8$-en-2-one scaffold (Fig. 1), which contains a highly substituted tetrahydrofuran ring with three quaternary carbons, is the main structural character which is critical for the biological activities (1).

The isolation and characterization of xanthones from the Garcinia plant were reviewed by Prof. Venka-taraman in 1973, but only nine caged xanthones were mentioned. Recently, over 40 different xanthones were isolated from $G$. hanburyi. Furthermore, multiple mechanisms of its cytotoxic activity have been reported, such as cell cycle arrest, apoptosis induction, telomerase inhibition, and anti-angiogenesis (2). Due to its diversity of bioactive ingredients and potent activities, a series of in-depth researches were conduct by researchers all over the world. The authors and his team have engaged in the

Buyun Jia and Shanshan Li contributed equally to this work.

${ }^{1}$ School of Pharmacy, Anhui University of Chinese Medicine, 001 Qianjiang Road, Hefei, 230012Anhui, China.

${ }^{2}$ Ma'anshan Central Hospital, 027 Hudong Road, Ma'anshan, 243000Anhui, China.

${ }^{3}$ To whom correspondence should be addressed. (e-mail: anzhongdong@126.com) study of xanthones from G. hanburyi, which is subsidized by the national key new drug discovery projects. Our work includes many aspects, such as isolation, formulation, and pharmacokinetics study. To make the direction of future study more clear, the author made the following conclusion of the recent research on these compounds.

\section{EXTRACTION AND ISOLATION METHODS}

The special class of caged xanthones from G. hanburyi can be isolated by different kinds of methods. The plant was usually extracted with certain kinds of organic solvents, and then the extract was loaded in the preparative chromatography for further isolation.

It was reported that three new compounds, along with six known compounds, were isolated from the EtOAc extract of gamboge using silica gel columns with different sizes and eluted with solvents of various proportions to give several fractions. Semipreparative high-performance liquid chromatography (HPLC) was used to give the purified compounds (Fig. 2). The isolated compounds are garcinolic acid (C1), 10 $\alpha-$ ethoxy-9,10-dihydromorellic acid (C2), 10 $\alpha$-ethoxy-9,10dihydrogambogenic acid (C3), deoxygaudichaudione A (C4), gambogenic acid (C5), desoxygambogenin (C6), hanburin (C7), gambogic acid (C8), and desoxymorellin (C9) (3).

Another new caged-tetraprenylated xanthone, hanburinone, together with four known caged-tetraprenylated xanthones, was isolated from the fresh fruits of G. hanburyi using column chromatography and preparative HPLC (Fig. 3). They are hanburinone (C1), isomoreollin $\mathrm{B}(\mathrm{C} 2)$, morellin (C3), moreollic acid (C4), and morellic acid (C5), respectively (4).

Gambogic acid and epigambogic acid were preparative isolated from $G$. hanburyi with a high-speed counter-current chromatographic system using $n$-hexane-methanol-water $(5: 4: 1, v / v / v)$ as the two-phase solvent system. $18.4 \mathrm{mg}$ 


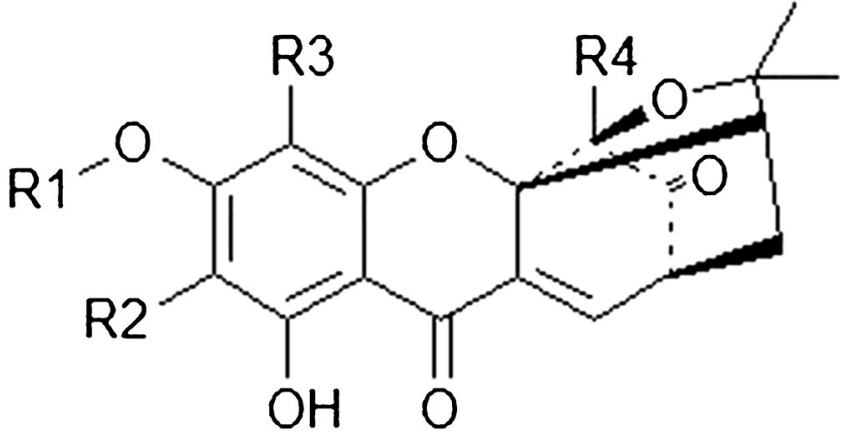

Fig. 1. The chemical skeleton of Garcinia xanthones

epigambogic acid and $28.2 \mathrm{mg}$ gambogic acid were isolated from $50 \mathrm{mg}$ of mixture compounds, whose purities were both above $97 \%$ (5). Besides, it was reported that another two polyprenylated xanthone epimers were separated from the resin of $G$. hanburyi using the preparative HPLC (Fig. 4) and identified as 30-hydroxygambogic acid (C1) and 30hydroxyepigambogic acid (C2), respectively (6).

The author was occupied with the research of gambogenic acid and mainly in charge of the isolation of gambogenic acid and other active ingredients from the gamboge (Fig. 5). The equipment we used was a medium-pressure preparative chromatography loaded with ODS silica gel. It can provide a fast way to get the relatively pure gambogenic acid which is one of the compounds that draws great interests.

\section{ANALYSIS OF THE BIOACTIVE INGREDIENTS}

For the purpose of in-depth investigation of the chemical composition, advanced analytical equipments were used in the studies of the caged xanthones from $G$. hanburyi. Among them, high-performance liquid chromatography (HPLC), ultra performance liquid chromatography (UPLC), and ultra performance liquid chromatography/tandem mass spectrometry (UPLC/MS) were used frequently.

Forbesione, isomorellic acid, morellic acid, $R-30$ hydroxygambogic acid, $S$-30-hydroxygambogic acid, isogambogenic acid, isogambogenin, isomorellinol, and one likely new compound were effectively separated and identified using an ultra high-performance liquid chromatography/ electrospray quadrupole time of flight tandem mass spectrometry (UHPLC-ESI-QTOF-MS/MS/MS) method proved to be efficient and rapid. Within $6 \mathrm{~min}$, all the compounds were separated (7).

$R$-Isogambogic acid, $S$-isogambogic acid, $R$-gambogic acid, $S$-gambogic acid, forbesione, isomorellic acid, morellic acid, $R$-30-hydroxygambogic acid, $S$-30-hydroxygambogic acid, isogambogenic acid, gambogenic acid, and gambogellic acid were separated with an improved HPLC method validated to be precise, sensitive, and accurate (8).

It was reported that a group of caged xanthones were separated by a highly effective qualitative method in which an HPLC and multiple mass spectrometric scanning modes consisting of full scanning (FS), precursor ion scanning (PrecIS), product ion scanning (PIS), and selected reaction monitoring (SRM) were selected for the qualitative analysis. The isolated compounds were forbesionic acid, isoforbesionic acid, gaudichaudionol, isogaudichaudionol, gaudichaudione A, isogaudichaudione $\mathrm{A}$, gaudichaudionic acid, isogaudichaudionic acid, morellin, isomorellin, desoxygambogenin, gambogeninol, forbesione, desoxygaudichaudione A, morellic acid, isomorellic acid, isogambogenin, gambogenic acid, isogambogenic acid, $S / R$-gambogic acid, $S / R$-isogambogic acid, $R$-30-hydroxyisogambogic acid, $S$-30-hydroxygambogic acid, and hanburin, respectively (9).

Some of the epimers which are difficult to separate using the common column exist in G. hanburyi. So, the ion-pair HPLC is needed in the separation works of these kinds of caged Garcinia xanthones. For example, three pairs of epimers, including isogambogic acid, epiisogambogic acid, 30hydroxygambogic acid, 30-hydroxyepigambogic acid, gambogic acid, and epigambogic acid, were analytical separated from the resin of G. hanburyi using a rapid ion-pair HPLC method. The separation was performed on a narrow bore $\mathrm{C}_{8}$ column with isocratic elution using a mixture of methanolACN-40 mM KH $2 \mathrm{PO}_{4}$ buffer (37.5:37.5:25 v/v/v, containing $0.1 \%$ tetradecyltrimethylammonium bromide). This method provided a specific and fast solution for the determination of the epimers, which is crucial for the quality control of gamboge (10).

An analytical method was developed for the determination of gambogic acid in human plasma using a highperformance liquid chromatography-atmospheric pressure chemical ionization-mass spectrometry (HPLC-APCI-MS) method, which was worked in the selected ion monitoring (SIM) mode with target ions at $(\mathrm{M}-\mathrm{H})^{-} \mathrm{m} / \mathrm{z} 627.4$ for gambogic acid and $(\mathrm{M}-\mathrm{H})^{-} \mathrm{m} / z, 455.4$ for the I.S. The method can be applied to monitoring of gambogic acid in the future clinical treatment (11).

Currently known Garcinia xanthones are listed in Table I.

\section{MODIFICATION OF XANTHONES}

Shortages of these compounds, such as poor water solubility, short half-life, and vessel irritation, need to be overcome. Therefore, various modification methods were used to make these compounds more suitable therapeutic drugs for clinical applications.

Due to the poor water solubility, the application of gambogic acid was limited. Therefore, water-soluble gambogic acid PEGylated prodrugs were prepared and investigated both in vitro and in vivo. The result showed that the solubility of gambogic acid was dramatically enhanced. Moreover, an in vivo study suggested that the half-life $\left(t_{1 / 2}\right)$ of PEGylated gambogic acid in plasma ranged from 1.26 to $6.12 \mathrm{~h}$, which is much longer then that of gambogic acid itself. The stability of the gambogic acid PEGylated prodrugs was significantly improved with increasing molecular weight of PEG (12).

An oxidative analog of gambogic acid was synthesized, and the newly synthesized analog of gambogic acid showed potential antitumor activity by inducing apoptosis in HepG2 cells (13).

Two new products which were different from reported Garcinia natural products were got by treated gambogic acid with methanol in acidic condition under microwave irradiation. Both of the two modified compounds could dramatically inhibit the growth of various cancer cell lines such as HepG2, BGC-803, and SGC-7901 (14). 


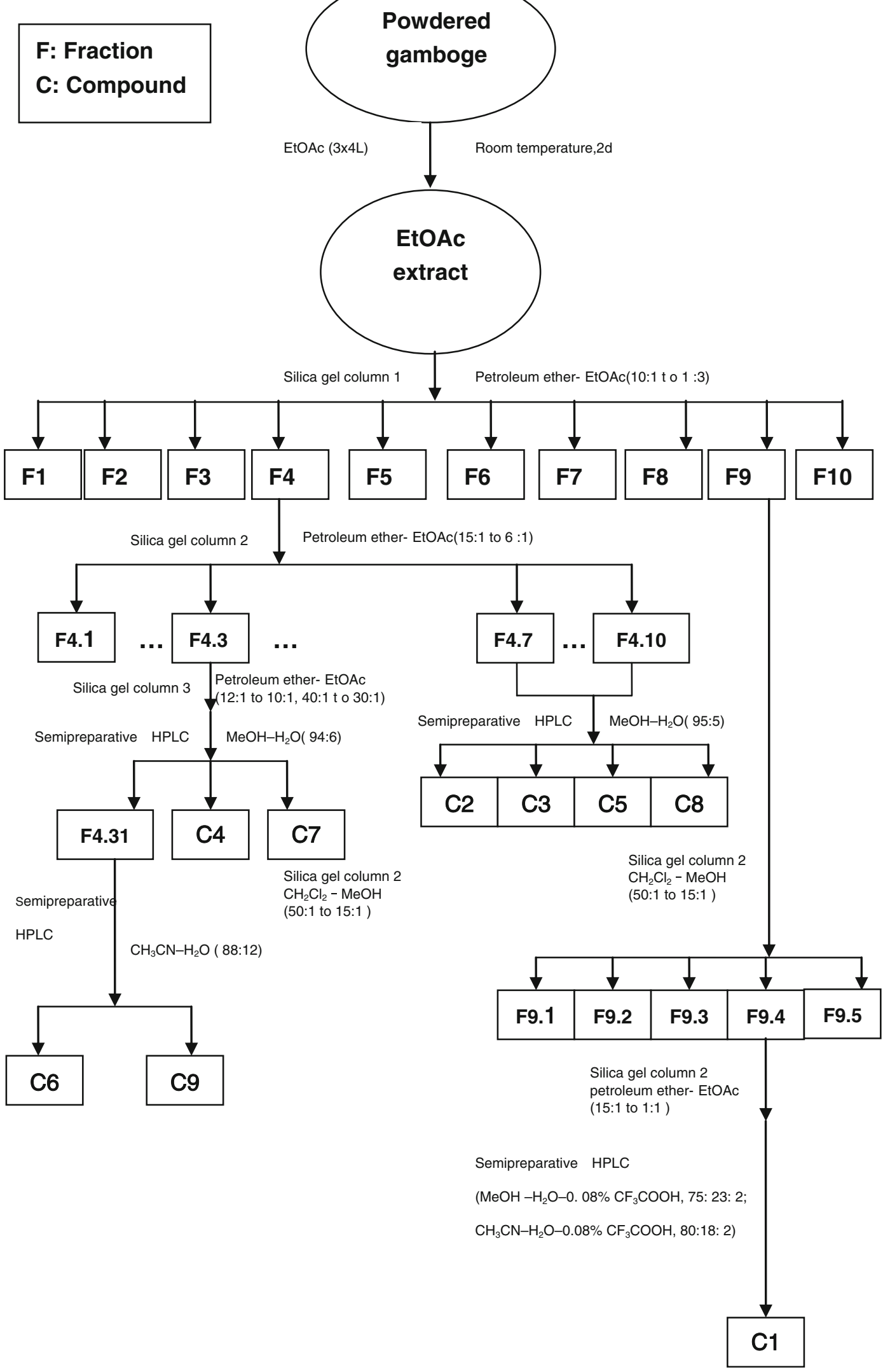

Fig. 2. Isolation method of nine compounds from gamboge

Thirteen novel compounds were obtained by modification of gambogic acid via a base-catalyzed diene intramolecular annelation, and their inhibitory activity on HT-29, Bel-7402, BGC-823, and A549 cell lines were evaluated in vitro. Among 


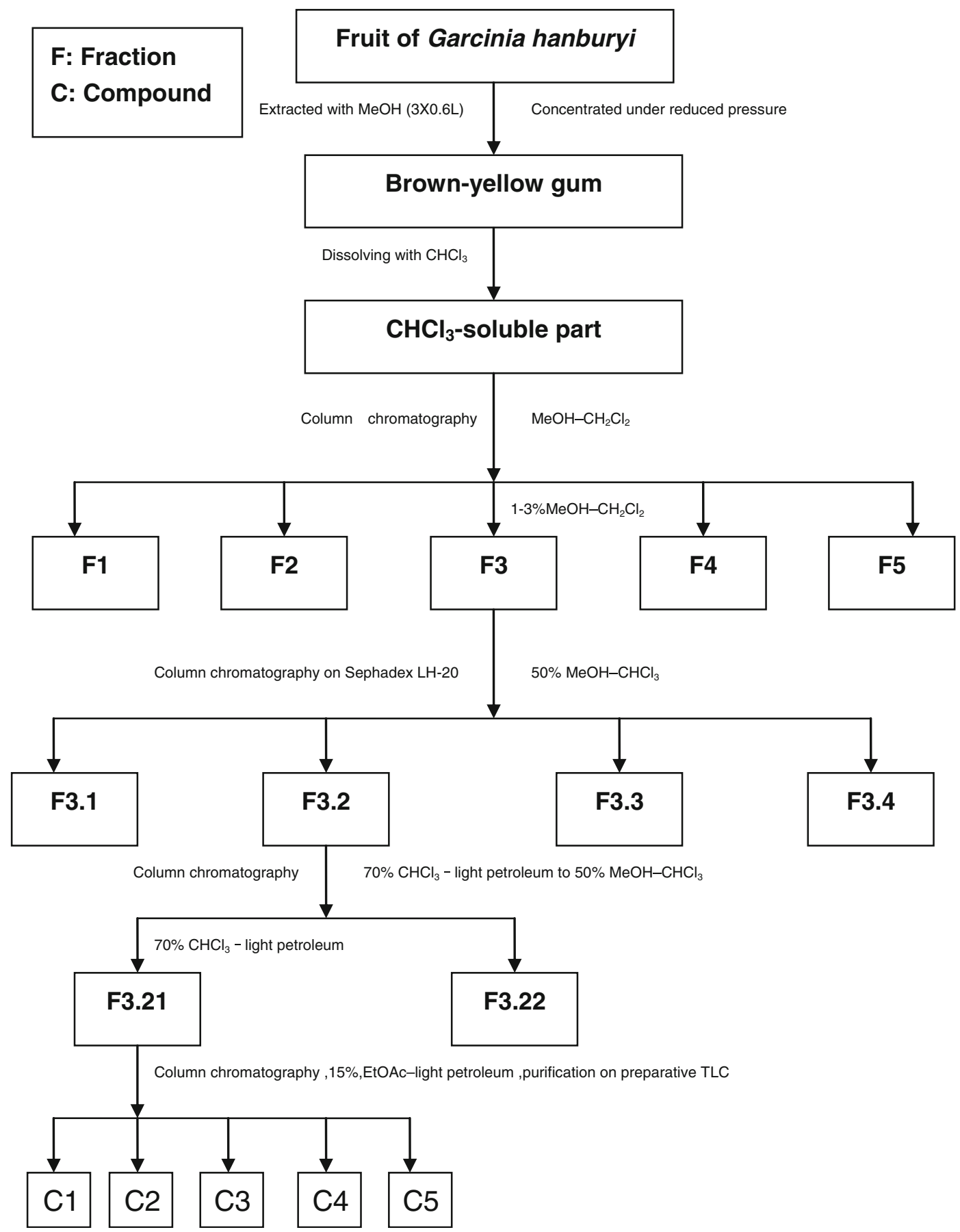

Fig. 3. Isolation method of five compounds from the fruit of Garcinia hanburyi

these compounds, $(38,40)$-epoxy-33-chlorogambogellic acid was found to be a BGC-823 cell apoptosis inducer which showed strong effects in inducing apoptosis (15).

In another study carried out by the expert from China Pharmaceutical University, 11 oxidized derivatives of gambogic acid were synthesized. Some of them showed dramatic inhibitory effects on A549, Bel-7402, BGC-823, HT-29, and SKOV 3 cell lines. Among them, 9-hydroxy-6-methoxygambogic acid methyl ester may act as a potential lead compound for the development of novel anticancer drugs. The result also suggests that modification of the compound on certain structures can improve its antitumor effect (16).
Gambogic acid-loaded micelles were prepared using chitosan derivatives, whose physical properties and stability were also evaluated. The result suggested that the solubility and stability were both improved dramatically by the delivery system (17).

Gambogic acid-loaded poloxamer 407/TPGS mixed micelles were prepared as a drug delivery system via a thin film hydration method. Physicochemical properties, cellular accumulation, and cytotoxicity of the drug delivery system were investigated. The result showed that the gambogic acid-loaded poloxamer 407/TPGS mixed micelles have a good entrapment efficiency, stability, and stronger cytotoxic activity compared with gambogic acid solution (18). 


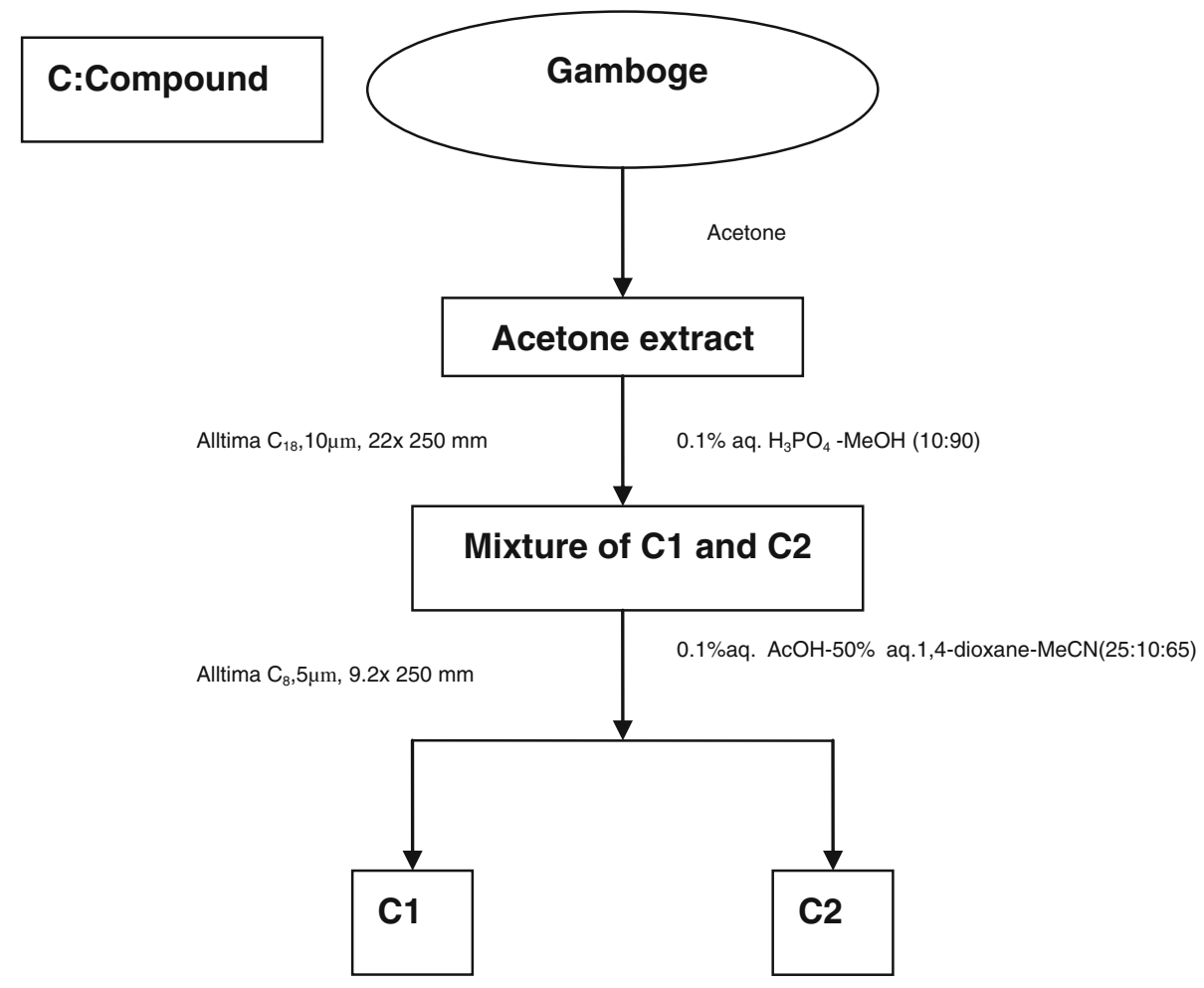

Fig. 4. Isolation method of two compounds from gamboge

Gambogic acid-loaded OACS ( $N$-octyl- $N$-arginine-chitosan) micelles were prepared using a dialysis method. The solubility and the absorption of gambogic acid were dramatically enhanced, which suggested that OACS micelles as an oral drug delivery system may have potential application values (19).
Gambogic acid-lactoferrin nanoparticles were successfully prepared through the nanoparticle albumin-bound (NAB) technology for the oral delivery. Gambogic acid-lactoferrin nanoparticles showed a better stability and a slow-release behavior. Moreover, it also proved to have a higher inhibitory

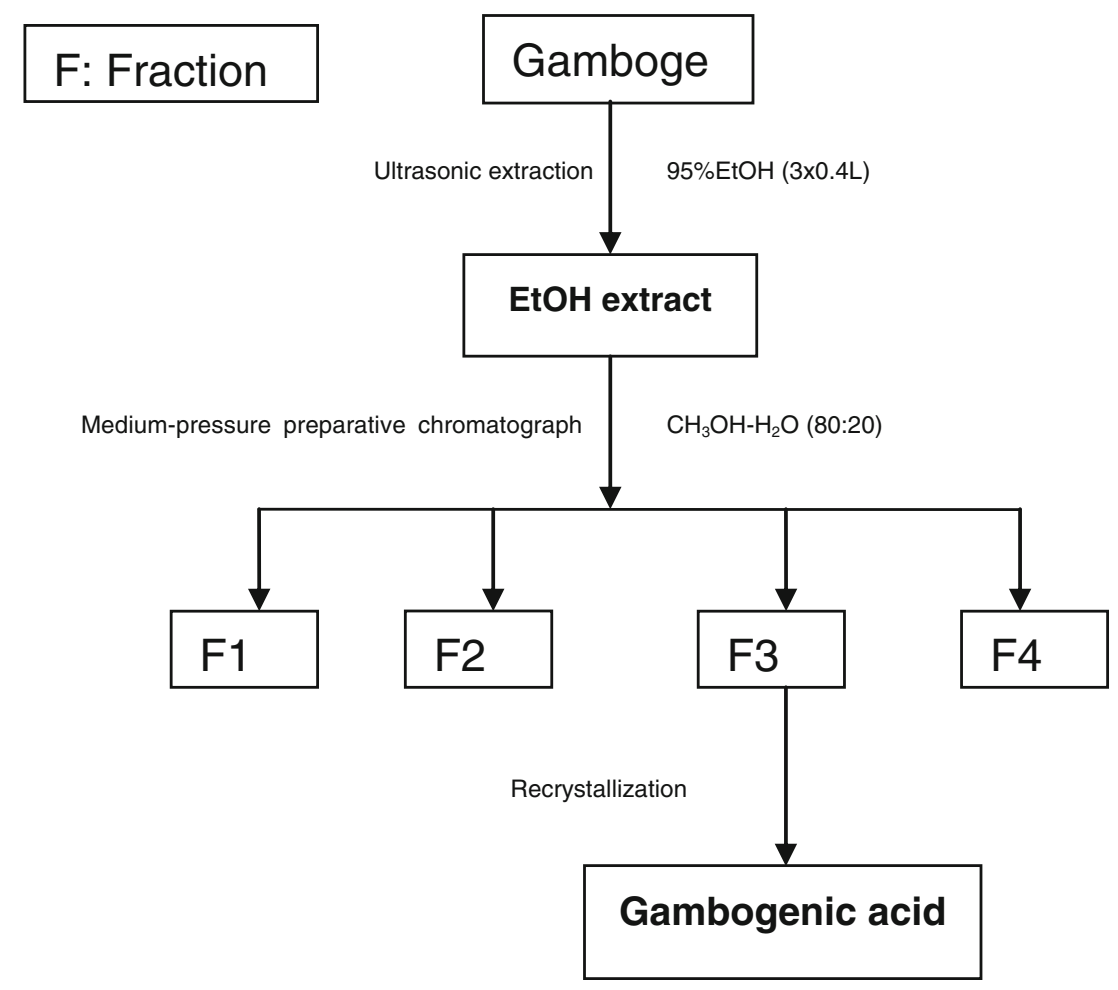

Fig. 5. Isolation method of gambogenic acid 
Table I. Chemical Structure of the Active Ingredients from Garcinia hanburyi

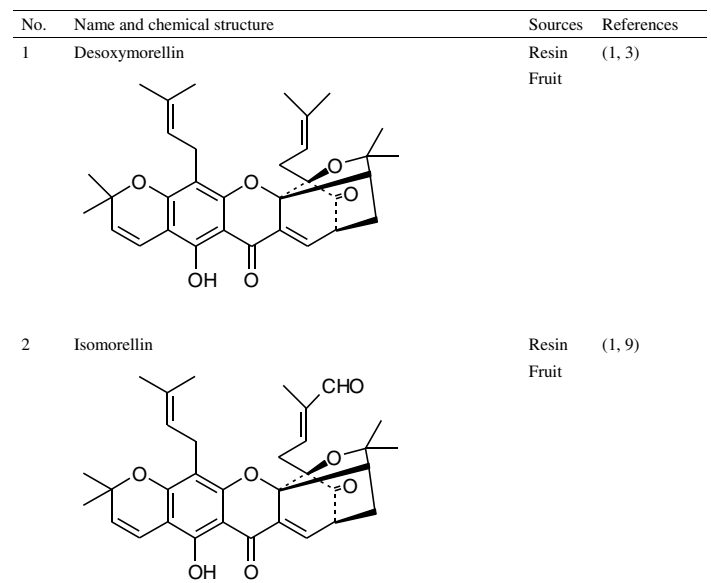

3

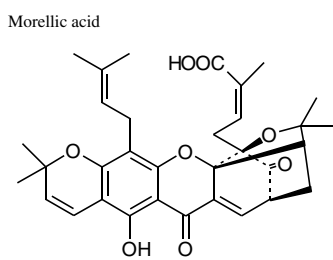

4 Isomorellic acid

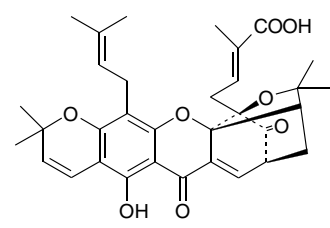

5 Isomorellinol

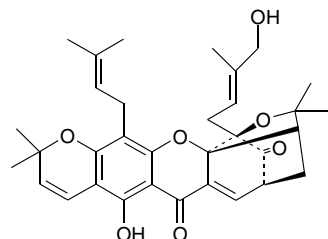

6

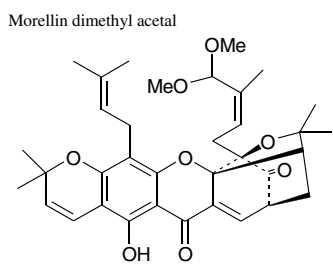

Gambogin

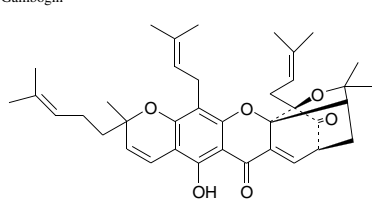

Gambogic aldehyde

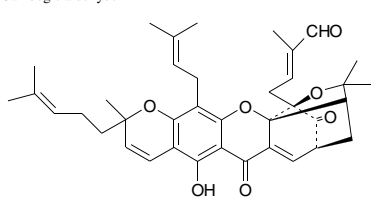

Resin $\quad(1,7,8)$

Resin $\quad(1,7)$

Fruit

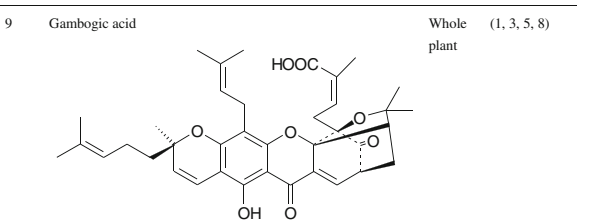

$10 \quad$ Epigambogic acid Resin $\quad(1,5,10)$

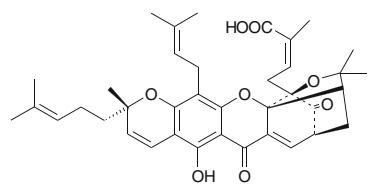

11 Isogambogic acid Resin $\quad(1,8,10)$

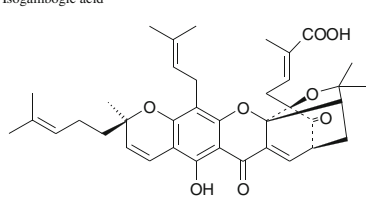

12 Epiisogambogic acid

Resin $\quad(1,10)$

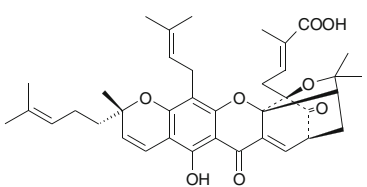

$13 \quad 30$-Hydroxygambogic acid

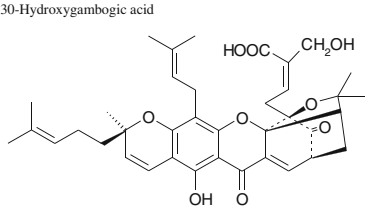

Resin $\quad(1,6-10)$

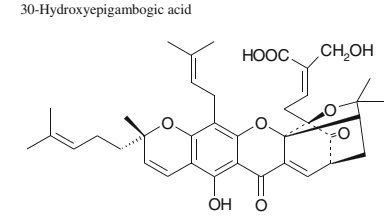

15
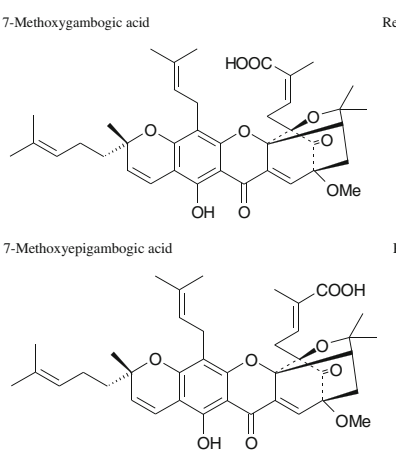

17

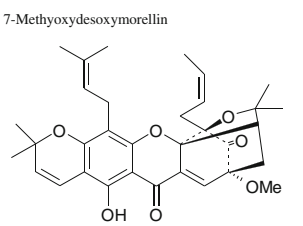

Resin $\quad(1,6)$ (1)

Table I. (continued) 

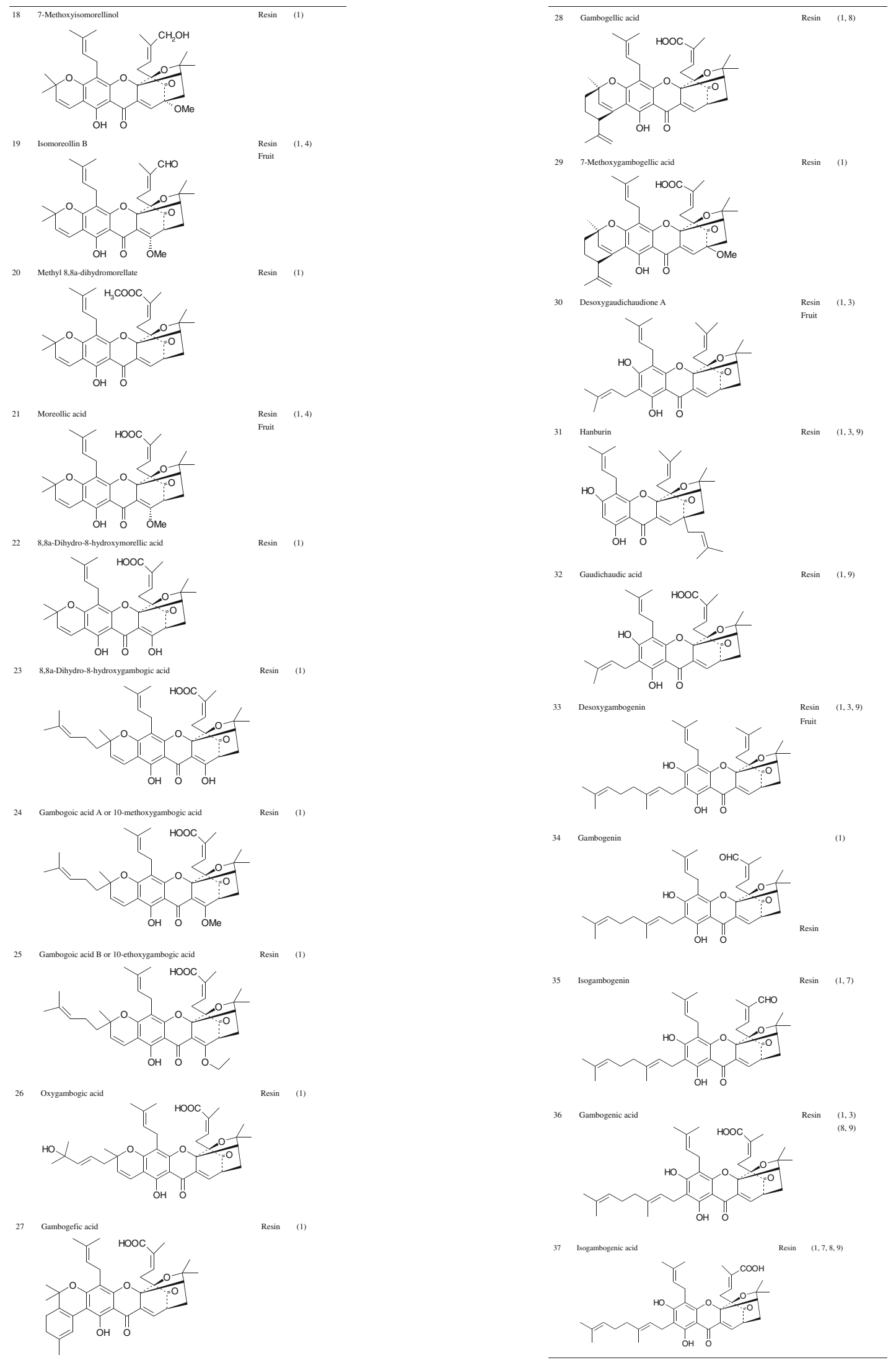

Resin $(1,9)$

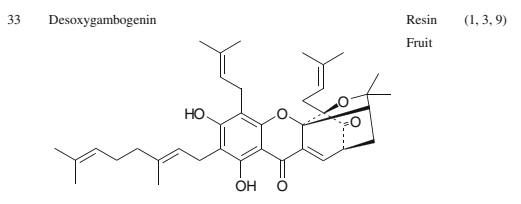

$34 \quad$ Gambogenin
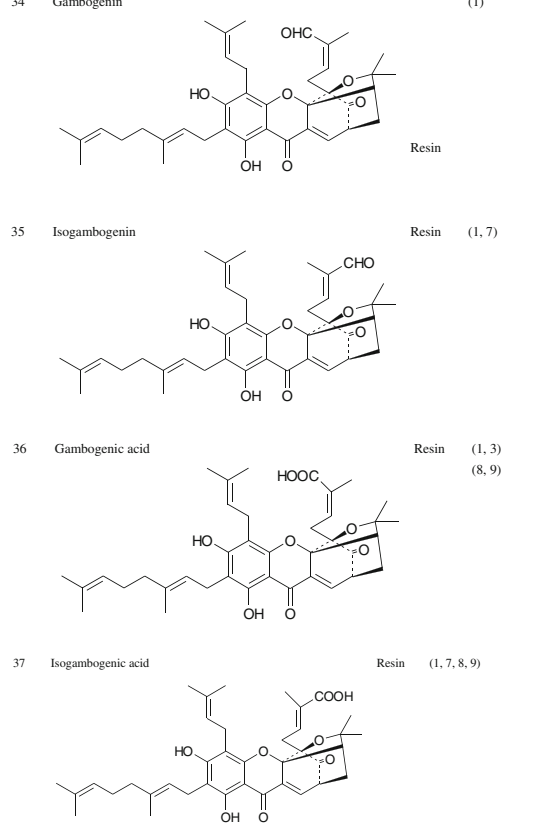

Table I. (continued)

Table I. (continued) 


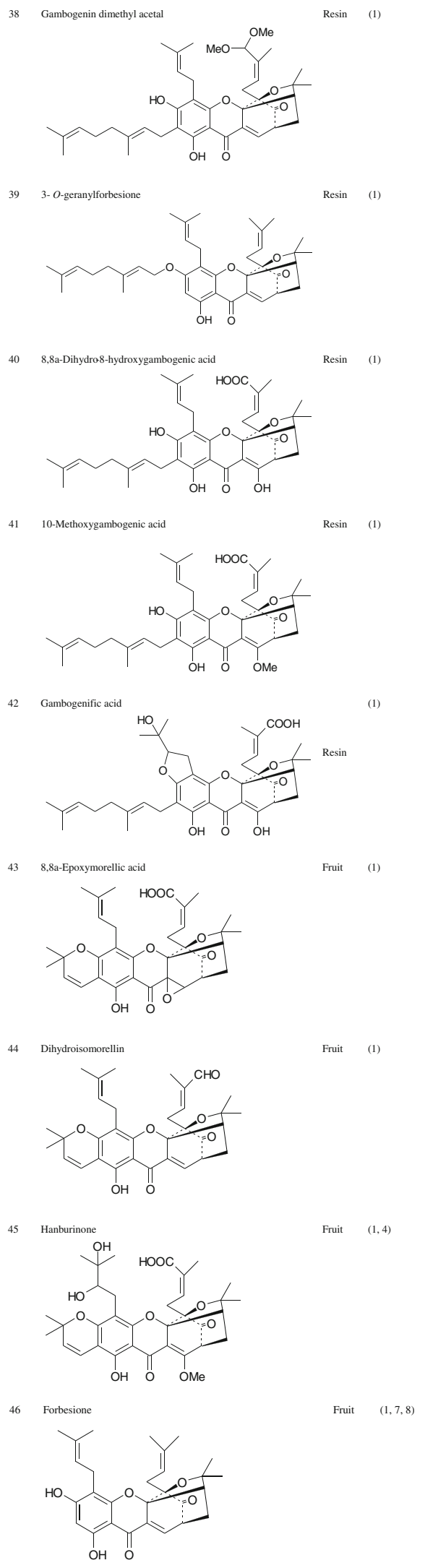

Table I. (continued) rate against S180 tumor mice after oral administration which is 1.39 times higher than that of intravenous injection of arginine solution of gambogic acid (20).

Gambogic acid was successfully connected with the magnetic nanoparticle (MNP)- $\mathrm{Fe}_{3} \mathrm{O}_{4}$ by mechanical absorption polymerization to prepare gambogic acid-MNP- $\mathrm{Fe}_{3} \mathrm{O}_{4}$ as a drug delivery system. The combination of gambogic acid and MNP$\mathrm{Fe}_{3} \mathrm{O}_{4}$ dramatically improved the water solubility and the anticancer activity of gambogic acid against Capan-1 pancreatic cancer cells, which made a further step approach the clinical application of gambogic acid (21). The effects caused by gambogic acid-MNP-Fe $\mathrm{O}_{4}$ on the growth of Panc-1 pancreatic cancer cells were also tested. Gambogic acid-MNP-Fe ${ }_{3} \mathrm{O}_{4}$ can dramatically inhibit cancer cell proliferation and prevent cells from migrating which was partly because gambogic acid-MNP$\mathrm{Fe}_{3} \mathrm{O}_{4}$ suppressed the expression of ETS1, along with its downstream target genes for u-PA, cyclin D1, and VEGF (22).

The result of the in-depth investigations indicated that these kinds of modified compounds and Garcinia xanthoneloaded drug delivery systems can improve the solubility, bioactivity, and stability of the compounds. Furthermore, the in vivo study suggested that a longer half-life, larger area under concentration-time curve (AUC), and relatively smaller side effect were found compared with the pure compound.

\section{IN VIVO STUDIES}

\section{Pharmacokinetics Studies}

The plasma pharmacokinetics, tissue distribution, and excretion of gambogic acid, a promising antitumor drug candidate, were studied after i.v. administration in SD rats at the doses of 1,2 , and $4 \mathrm{rng} / \mathrm{kg}$. The elimination half-life $\left(t_{1 / 2}\right)$ values of gambogic acid were 14.9, 15.7, and $16.1 \mathrm{~min}$, respectively. The mean AUC values were 54.2, 96.1, and $182.4 \mu \mathrm{g} \cdot \mathrm{min} / \mathrm{mL}$, and most of the gambogic acid seemed to be excreted into the bile within $16 \mathrm{~h}$ of administration. It was found that the short half-life of gambogic acid may be due to its rapid tissue distribution. After i.v. administration, the highest drug concentration was found in the liver. So, the high liver uptake of gambogic acid may result in its high ratio of bile extraction (23).

A pharmacokinetics study of gambogic acid injection in six beagle dogs was conducted using a LC-MS/MS method. The result suggested that the method established by the researchers is suitable for the in vivo analysis. However, the drug concentration-time curve showed that gambogic acid has a short half-life, so it has to depend on some formulation method to overcome the shortage (24).

A validated HPLC method was established to study the pharmacokinetics behavior of gambogic acid in dog plasma after i.v. $0.5,1$, and $2 \mathrm{mg} / \mathrm{kg}$ gambogic acid to 12 beagle dogs. The result indicated that $t_{1 / 2}$ and $\mathrm{CL}_{\mathrm{t}}$ did not change dramatically with doses. The $t_{1 / 2}$ values were determined to be 57.9, 59.2, and $60.9 \mathrm{~min}$, respectively. The $\mathrm{CL}_{\mathrm{t}}$ values ranged from 7.5 to $8.5 \mathrm{~mL} / \mathrm{kg} / \mathrm{min}$, respectively. However, the AUC increased with increasing doses. The AUC values were calculated to be $49.5,116.6$, and $150.9 \mu \mathrm{g} \cdot \mathrm{min} / \mathrm{mL}$, respectively. 
Additionally, the result of dose range studies exhibited that the pharmacokinetics of gambogic acid in beagle dogs was linear (25).

The metabolism of gambogic acid was investigated in vivo in rat bile using high-performance liquid chromatography (HPLC), HPLC/nuclear magnetic resonance, and HPLC/ion trap electrospray ionization-mass spectrometry. Four main metabolites were identified, and in the process of metabolism, gambogic acid was first oxidized by oxidase and then combined with glucuronide. There are several olefinic bonds in the chemical structure of gambogic acid. However, the 9,10-olefinic bond was the most likely to be oxidized among them since it was not only in the $\alpha, \beta$-unsaturated ketone structure system but also in a unique rigid bridged ring system (26).

The metabolism of gambogic acid was studied in rats. A rare intestinal metabolic pathway which involves Michael addition of the sulfite ion to the 9,10 carbon-carbon double bond of $\alpha, \beta$-unsaturated ketone was found to have a relationship with the process of the metabolism of gambogic acid. Moreover, it was also reported that gambogic acid might be metabolized by various routes, including mono oxidation, hydration, glucosidation, glucuronidation, and glutathionylation in the liver of rats (27).

The pharmacokinetics study in SD rats of gambogenic acid solution and gambogenic acid-loaded solid lipid nanoparticles (GNA-SLNs) was carried out by the senior author, and the result indicated that the GNA-SLNs showed a better performance than the gambogenic acid solution, which has a relatively long half-life and improved safety. The AUC value of GNA-SLNs was 3.11 times larger than that of gambogenic acid solution, and the $t_{1 / 2}$ was 1.29 times longer than that of gambogenic acid solution. Moreover, the higher level of safety was confirmed by hemocompatibility test and vascular irritation test. The result of both tests indicated that the GNASLNs may have a relatively small side effect compared with gambogenic acid solution (28).

The short half-life of gambogic acid is probably caused by the metabolic inhibition effect induced by CYP1A2 which is major rat CYP involved in the metabolism process of gambogic acid. Therefore, inhibition of the related metabolic pathway can lower the formation rate of metabolites and increase the concentration of gambogic acid, suggesting pharmaceutical modifications and metabolic interactions of gambogic acid with other therapeutic agents may help this process (29).

\section{Pharmacological Studies}

It was reported that for the purpose of proving the antitumor effects of gambogic acid against glioblastoma in vivo, rats which were injected $\mathrm{C} 6$ glioma cells were treated with gambogic acid or a vehicle for 2 weeks starting $24 \mathrm{~h}$ after glioma cell injection. The gambogic acid-treated rats showed a significant reduction of tumor volume after 14 days of treatment compared with vehicle-treated rats. It was found that gambogic acid might be able to enter the blood-brain barrier and affect the central nervous system. The results of cytotoxicity test indicated that gambogic acid can inhibit the growth of C6 glioma cells in a concentration-dependent manner and the $\mathrm{IC}_{50}$ value was determined to be $1.2 \mathrm{mmol} / \mathrm{L}$. In addition, gambogic acid can upregulate the expression of Bax and pro-caspase- 3 and downregulate the expression of Bcl-2, which indicated that gambogic acid might induce cell apoptosis in vivo (30).

Gambogic acid also showed dramatic anti-metastasis activity on the growth of artificial metastases in vivo in C57BL/6 mice injected with B16-F10 melanoma tumor cells by suppressing $\alpha 4$ integrin expression. Further results suggested that gambogic acid could inhibit the adhesion and migration of B16-F10 cells. Therefore, it might be a promising antimetastasis drug (31).

Gambogic acid dramatically inhibited the lung metastases and xenograft tumor growth in athymic BALB/c nude mice infecting MDA-MB-231 human breast carcinoma cells. The inhibition effect might have a relationship with the fact that treatment with gambogic acid induced apoptosis and accumulated the amount of reactive oxygen species (ROS) in MDAMB-231 cells. In addition, gambogic acid could induce activation of caspase- 3 , caspase- 8 , and caspase- 9 , as well as an increasing ratio of $\mathrm{Bax} / \mathrm{Bcl}-2$. Moreover, the translocation of apoptotic inducing factor (AIF) and the release of cytochrome c (Cyt c) from mitochondria were also found, suggesting that gambogic acid induced apoptosis through the accumulation of ROS and the mitochondrial apoptotic pathway. Gambogic acid also inhibited cell proliferation via blocking the Akt/ mTOR pathway (32).

General gambogic acid was tested for its antitumor activity against human hepatoma SMMC-7721 cells in nude mice. The result showed that the growth of SMMC-7721 tumor in nude mice was significantly inhibited after i.v. injection of general gambogic acid 2,4 , and $8 \mathrm{mg} / \mathrm{kg}$. The result also indicated that gambogic acid could significantly inhibit the activity of telomerase which is one of the crucial enzymes for the replication of RNA and a kind of ribo-nucleoprotein in SMMC-7721 (33).

Besides the strong cytotoxicity, the in vivo antitumor activity might also have a relationship with the inhibition effect on angiogenesis of gambogic acid. It is reported that gambogic acid can reduce the vascular endothelial growth factor (VEGF)-induced human umbilical vein endothelial cells (HUVEC) proliferation, mobility, and tube formation. The microvessel counts (MVCs) test which is conducted in vivo indicated that the mean intratumoral microvessel densities of gambogic acid-treated rats were dramatically reduced compared with the control group (30). The results of the in vivo experiment indicated that gambogic acid is able to dramatically inhibit angiogenesis by inhibiting vascular endothelial growth factor-triggered tyrosine phosphorylation of KDR/Flk-1 (34). It was also found that gambogic acid inhibited the activity of vascular endothelial growth factor receptor 2 and its downstream protein kinases, such as focal adhesion kinase, c-Src, and AKT, which give rise to inhibition of angiogenesis and antitumor activity (35). Moreover, the anti-angiogenic effects also proved to have a relationship with the inhibition of the PHD2-VHL-HIF-1 $\alpha$ pathway induced by gambogic acid (36). 


\section{Toxicity Studies}

The toxicity of gambogic acid was tested using beagle dogs and albino mice as experimental animals, and the result indicated that the $\mathrm{LD}_{50}$ of gambogic acid was 45 $96 \mathrm{mg} / \mathrm{kg}$. Moreover, the chronic toxicity studies showed that the toxicity targets in the model animals were the kidney and liver. It is reported that after gambogic acid i.v. administration, the most significant levels were observed in the liver, which was also in good agreement with the results of the above toxicological investigations. The study of the toxicity set a foundation for clinical applications of gambogic acid $(23,37)$.

The chronic toxicity of gambogic acid was tested in rats. The results of the studies suggested that the damage on the kidney and liver can be caused by treating with a high dose $(120 \mathrm{mg} / \mathrm{kg})$ of gambogic acid for a long time. A safe dose was developed to be $60 \mathrm{mg} / \mathrm{kg}$ after administration to rats for 13 weeks at a frequency of a single administration every other day (38).

The general pharmacological toxicity of gambogic acid, a new anticancer agent, on the dog cardiovascular and respiratory systems and the mouse central nervous system (CNS) was investigated. The results indicated that gambogic acid did not lead to any toxic symptoms on blood pressure, respiratory frequency, and heart rate (HR) while a high dose of gambogic acid exhibited slight side effects on the mouse CNS. The above results were also partly because gambogic acid might be able to enter the blood-brain barrier. $(30,39)$.

\section{IN VITRO STUDIES}

\section{Cytotoxic Activity}

Caged xanthones isolated from G. hanburyi showed cytotoxic activities against many cell lines such as human lung carcinoma cells (A549), Henrietta Lacks cervical carcinoma tumor cells (HeLa), human hepatoma (SMMC-7221), human leukemia K562 (K562/S), doxorubicin-resistant K562 (K562/R), human colon carcinoma cells (HCT116), human breast carcinoma cells (SK-BR-3), human hepatocellular carcinoma cells (HepG2), human liver cancer cells (Hep3B), human liver cancer cells (Huh7), and human euroblastoma cells (SH-SY5Y).

Garcinolic acid, acid deoxygaudichaudione A, gambogenic acid $10 \alpha$-ethoxy-9,10-dihydromorellic acid, $10 \alpha$ ethoxy-9,10-dihydrogambogenic desoxygambogenin, hanburin, gambogic acid, and desoxymorellin showed high inhibitory effects on human lung carcinoma cells (A549), human colon carcinoma cells (HCT116), human breast carcinoma cells (SK-BR-3), and human hepatocellular carcinoma cells $(\mathrm{HepG} 2)$ with the $\mathrm{IC}_{50}$ values which were all below $10 \mu \mathrm{M}(2)$.

Gaudichaudic acid, isogambogenic acid, deoxygaudichaudione A, gambogoic acid A, gambogenic acid, desoxygambogenin, isomorellic acid, morellic acid, desoxymorellin, and isomorellinol which were found from the resin of $G$. hanburyi exhibited significant cytotoxicities against human leukemia K562 (K562/S) and doxorubicin-resistant K562 $(\mathrm{K} 562 / \mathrm{R})$ cell lines with the $\mathrm{IC}_{50}$ value range of $0.11-3.04 \mu \mathrm{g} / \mathrm{mL}$ (40). Moreover, 30-hydroxygambogic acid and its $(2 S)$-epimer 30-hydroxyepigambogic acid were tested for their cytotoxicities against the above two cell lines and the result indicated that 30hydroxyepigambogic acid showed reduced activities compared with 30-hydroxygambogic acid (5).

Isomorellin, isomorellinol, forbesione, and gambogic acid were tested against KKU-100 and KKU-M156. The result indicated that the inhibition effect on both cell lines was found and growth inhibition induced by these compounds might be due to apoptosis (41).

It was reported that gambogic acid, a highly concerning compound from $G$. hanburyi, inhibited the growth of human liver cancer cells (Hep3B and Huh7) and human neuroblastoma cell (SH-SY5Y) viability with $\mathrm{IC}_{50}$ values of $1.8,2.2$, and $1.28 \mu \mathrm{M}$, respectively $(42,43)$.

Gambogenic acid and its microbial transformation product 16,17-dihydroxygambogenic acid were evaluated for their cytotoxicity against human cervical carcinoma cells (HeLa), but only modest activity was shown from both of the compounds (44).

Another research reported that gambospiroene methyl, 8,8a-dihydromorellate, 3-O-geranylforbesion, gambogefic acid, 7-methoxygambogellic acid, 7-methoxygambogic acid, 7methoxyepigambogic acid 8,8a-dihydro-8-hydroxymorellic acid, 8,8a-dihydro-8-hydroxygambogenic acid, oxygambogic acid, gambogenific acid, 7-methoxyisomorellinol 8,8a-dihydro-8hydroxygambogic acid, and 8,8a-dihydro-8-hydroxygambogic acid were also tested for their cytotoxic effect against HeLa cells. All compounds displayed potent cytotoxicity except methyl 8,8a-dihydromorellate (45).

KKU-10 0 and KKU-M156 CCA cells were dramatically inhibited by isomorellin which is a caged xanthone isolated from $G$. hanburyi with $\mathrm{IC}_{50}$ values of $6.2 \pm 0.13,5.1 \pm 0.11$, and $3.5 \pm 0.25 \mu \mathrm{M}$ at 24,48 , and $72 \mathrm{~h}(46)$.

It was found that the efficiency of cell growth inhibition increased dramatically when the concentration of gambogic acid was increased. A liner regression of the data allowed the calculation of the $\mathrm{IC}_{50}$ of gambogic acid for human hepatoma SMMC-7721, which is $1.2 \mu \mathrm{M}$ with $48 \mathrm{~h}$ exposure (47).

Different apoptotic induction of gambogic acid on human hepatoma SMMC-7721 cells and human normal embryo hepatic L02 cells was compared by observing morphological changes, detecting growth inhibition, and the expressions of the relative apoptotic proteins, which indicated that gambogic acid could selectively induce apoptosis of human hepatoma SMMC-7721 cells, while had a relatively small effect on human normal embryo hepatic L02 cells (48).

Gambogic acid was also tested for its inhibitory effect against Jurkat T cells. And the result showed that gambogic acid has a significant inhibition effect on Jurkat T cells with the $\mathrm{IC}_{50}$ values of $1.51 \pm 0.09(24 \mathrm{~h}), 0.98 \pm 0.13(48 \mathrm{~h})$, and $0.67 \pm$ $0.12 \mu \mathrm{mol} / \mathrm{L}(72 \mathrm{~h})$. Gambogic acid can also induce apoptosis in Jurkat cells (49).

Table II summarizes some of the results of cytotoxic tests of $G$. xanthones.

\section{Anti-HIV Activity}

Recently, the anti-HIV activity of the caged xanthones from G. hanburyi was also mentioned in some of the researches. For example, 2-acetoxyalphitolic acid and 3-acetox yalphitolic acid, 
Table II. Cytotoxic Activity of Garcinia Xanthones

\begin{tabular}{|c|c|c|c|c|}
\hline No. & Compound & Cell lines & $\mathrm{IC}_{50(\mu \mathrm{g} / \mathrm{mL})}$ & Reference \\
\hline \multirow[t]{6}{*}{$\overline{1}$} & \multirow[t]{6}{*}{ Deoxygaudichaudione A } & A549 & $3.12(72 \mathrm{~h})$ & (3) \\
\hline & & HCT116 & $0.78(72 \mathrm{~h})$ & (3) \\
\hline & & SK-BR-3 & $2.49(72 \mathrm{~h})$ & (3) \\
\hline & & HepG2 & $2.75(72 \mathrm{~h})$ & (3) \\
\hline & & K562/ADR & $3.04(44 \mathrm{~h})$ & (13) \\
\hline & & K562/S & $1.74(44 \mathrm{~h})$ & (13) \\
\hline \multirow[t]{6}{*}{2} & \multirow[t]{6}{*}{ Desoxygambogenin } & A549 & $3.12(72 \mathrm{~h})$ & (3) \\
\hline & & HCT116 & $4.02(72 \mathrm{~h})$ & (3) \\
\hline & & SK-BR-3 & $2.80(72 \mathrm{~h})$ & (3) \\
\hline & & HepG2 & $4.99(72 \mathrm{~h})$ & (3) \\
\hline & & K562/ADR & $2.43(44 \mathrm{~h})$ & (13) \\
\hline & & $\mathrm{K} 562 / \mathrm{S}$ & $0.91(44 \mathrm{~h})$ & (13) \\
\hline \multirow[t]{6}{*}{3} & \multirow[t]{6}{*}{ Desoxymorellin } & A549 & $1.42(72 \mathrm{~h})$ & (3) \\
\hline & & HCT116 & $0.28(72 \mathrm{~h})$ & (3) \\
\hline & & SK-BR-3 & $0.61(72 \mathrm{~h})$ & (3) \\
\hline & & HepG2 & $0.85(72 \mathrm{~h})$ & (3) \\
\hline & & K562/ADR & $1.53(44 \mathrm{~h})$ & $(40)$ \\
\hline & & K562/S & $0.64(44 \mathrm{~h})$ & (40) \\
\hline \multirow[t]{8}{*}{4} & \multirow[t]{8}{*}{ Gambogenic acid } & A549 & $3.14(72 \mathrm{~h})$ & (3) \\
\hline & & HCT116 & $3.50(72 \mathrm{~h})$ & (3) \\
\hline & & SK-BR-3 & $1.66(72 \mathrm{~h})$ & (3) \\
\hline & & HepG2 & $1.80(72 \mathrm{~h})$ & (3) \\
\hline & & K562/ADR & $3.90(48 \mathrm{~h})$ & (50) \\
\hline & & $\mathrm{K} 562 / \mathrm{S}$ & $3.01(44 \mathrm{~h})$ & (40) \\
\hline & & CICC 2445 & $2.41(44 \mathrm{~h})$ & (40) \\
\hline & & & $1.22^{\mathrm{a}}$ & (44) \\
\hline \multirow[t]{28}{*}{5} & \multirow[t]{28}{*}{ Gambogic acid } & A549 & $1.20(72 \mathrm{~h})$ & (3) \\
\hline & & HCT116 & $0.50(72 \mathrm{~h})$ & (3) \\
\hline & & SK-BR-3 & $1.16(72 \mathrm{~h})$ & (3) \\
\hline & & HepG2 & $1.02(72 \mathrm{~h})$ & (3) \\
\hline & & Hep3B & $1.80(24 \mathrm{~h})$ & (42) \\
\hline & & Huh7 & $2.20(24 \mathrm{~h})$ & (42) \\
\hline & & SH-SY5Y & $1.28(6 \mathrm{~h})$ & (43) \\
\hline & & MGC-803 & $0.96(48 \mathrm{~h})$ & (51) \\
\hline & & SPC-A1 & $1.74(24 \mathrm{~h})$ & (52) \\
\hline & & BGC-823 & $1.01(48 \mathrm{~h})$ & (52) \\
\hline & & $\mathrm{T} 47 \mathrm{D}$ & $0.81(72 \mathrm{~h})$ & (52) \\
\hline & & ZR751 & $2.30(24 \mathrm{~h})$ & $(53,54)$ \\
\hline & & HL60 & $1.41(48 \mathrm{~h})$ & (53) \\
\hline & & Jurkat & $1,02(72 \mathrm{~h})$ & (53) \\
\hline & & Calu1 & $0.63^{\mathrm{a}}$ & (55) \\
\hline & & MES & $0.40^{\mathrm{a}}$ & (55) \\
\hline & & MES ADR & $0.115^{\mathrm{a}}$ & (55) \\
\hline & & K562/S & $0.624(72 \mathrm{~h})$ & (56) \\
\hline & & K562/ADR & $0.168^{\mathrm{a}}$ & (55) \\
\hline & & MCF7 & $0.55^{\mathrm{a}}$ & (55) \\
\hline & & MDA-MB-468 & $0.30^{\mathrm{a}}$ & (55) \\
\hline & & SGC-7901 & $1.00^{\mathrm{a}}$ & (55) \\
\hline & & U937 & 0.28 (2 days) & (57) \\
\hline & & & $10.78(44 \mathrm{~h})$ & (58) \\
\hline & & & 0.24 (4 days) & (58) \\
\hline & & & 0.33 (5 days) & (58) \\
\hline & & & $2.0(48 \mathrm{~h})$ & (59) \\
\hline & & & $1.019(24 \mathrm{~h})$ & (60) \\
\hline \multirow[t]{2}{*}{6} & \multirow{2}{*}{ Gambogoic acid A } & K562/ADR & $1.65(44 \mathrm{~h})$ & $(40)$ \\
\hline & & K562/S & $1.38(44 \mathrm{~h})$ & (40) \\
\hline \multirow[t]{2}{*}{7} & \multirow[t]{2}{*}{ Gaudichaudic acid } & K562/ADR & $0.61(44 \mathrm{~h})$ & (40) \\
\hline & & K562/S & $0.41(44 \mathrm{~h})$ & (40) \\
\hline 8 & Isogambogic acid & K562/ADR & $2.86(44 \mathrm{~h})$ & $(40)$ \\
\hline & & K562/S & $2.10(44 \mathrm{~h})$ & (40) \\
\hline 9 & Isomorellic acid & K562/ADR & $1.86(44 \mathrm{~h})$ & (40) \\
\hline & & $\mathrm{K} 562 / \mathrm{S}$ & $0.91(44 \mathrm{~h})$ & (40) \\
\hline 10 & Morellic acid & K562/ADR & $2.29(44 \mathrm{~h})$ & (40) \\
\hline & & $\mathrm{K} 562 / \mathrm{S}$ & $1.48(44 \mathrm{~h})$ & (40) \\
\hline
\end{tabular}


Table II. (continued)

\begin{tabular}{|c|c|c|c|c|}
\hline No. & Compound & Cell lines & $\mathrm{IC}_{50(\mu \mathrm{g} / \mathrm{mL})}$ & Reference \\
\hline \multirow[t]{4}{*}{11} & Garcinolic acid & A549 & $2.84(72 \mathrm{~h})$ & (3) \\
\hline & & HCT116 & $1.77(72 \mathrm{~h})$ & (3) \\
\hline & & SK-BR-3 & $1.92(72 \mathrm{~h})$ & (3) \\
\hline & & HepG2 & $1.83(72 \mathrm{~h})$ & (3) \\
\hline \multirow[t]{4}{*}{12} & $10 \alpha$-Ethoxy-9,10-dihydromorellic & A549 & $4.86(72 \mathrm{~h})$ & (3) \\
\hline & acid & HCT116 & $1.68(72 \mathrm{~h})$ & (3) \\
\hline & & SK-BR-3 & $2.16(72 \mathrm{~h})$ & (3) \\
\hline & & HepG2 & $2.07(72 \mathrm{~h})$ & (3) \\
\hline \multirow[t]{4}{*}{13} & $10 \alpha$-Ethoxy-9,10-dihydrogambogenic acid & A549 & $9.19(72 \mathrm{~h})$ & (3) \\
\hline & & HCT116 & $3.63(72 \mathrm{~h})$ & (3) \\
\hline & & SK-BR-3 & $9.22(72 \mathrm{~h})$ & (3) \\
\hline & & HepG2 & $6.65(72 \mathrm{~h})$ & (3) \\
\hline \multirow[t]{4}{*}{14} & Hanburin & A549 & $5.94(72 \mathrm{~h})$ & (3) \\
\hline & & НCT116 & $4.25(72 \mathrm{~h})$ & (3) \\
\hline & & SK-BR-3 & $3.18(72 \mathrm{~h})$ & (3) \\
\hline & & HepG2 & $2.92(72 \mathrm{~h})$ & (3) \\
\hline \multirow[t]{2}{*}{15} & 30-Hydroxygambogic acid & $\mathrm{K} 562 / \mathrm{R}$ & $2.89^{\mathrm{a}}$ & (6) \\
\hline & & $\mathrm{K} 562 / \mathrm{S}$ & $1.27^{\mathrm{a}}$ & (6) \\
\hline \multirow[t]{2}{*}{16} & 30-Hydroxyepigambogic acid & $\mathrm{K} 562 / \mathrm{R}$ & $4.49^{\mathrm{a}}$ & (6) \\
\hline & & $\mathrm{K} 562 / \mathrm{S}$ & $3.61^{\mathrm{a}}$ & (6) \\
\hline 17 & 16,17-Dihydroxygambogenic acid & CICC 2445 & $4.25^{\mathrm{a}}$ & (44) \\
\hline
\end{tabular}

${ }^{a}$ Not mentioned

along with betulinic acid, and betulin, which were isolated from the leaves and twigs of $G$. hanburyi were reported to show antiHIV-1 activity with the $\mathrm{IC}_{50}$ values of $15.9,19.8,27.2$, and $11.6 \mu \mathrm{g} / \mathrm{mL}$, respectively (61)

Moreover, 7-methoxydesoxymorellin, 2-isoprenylforbesione and 8,8a-epoxymorellic acid, desoxymorellin, isomorellin, isomorellinol, gambogic acid, desoxygambogenin, hanburin, and forbesione were tested for their anti-HIV-1 activity. However, only desoxygambogenin and dihydroisomorellin showed significant anti-HIV-1 activity (62).

\section{Neurotrophic Activity}

Gambogic acid which proved to be a selective agonist for TrkA receptor showed a strongly neurotrophic activity by selectively binding to TrkA, inducing its tyrosine phosphorylation, provoking neurite outgrowth in PC12 cells, eliciting PI3-kinase/Akt and MAPK activation, and preventing neuronal cell death (63).

\section{Antibacterial Activity}

Caged xanthones which were isolated from G. hanburyi were evaluated for the antibacterial activity against several kinds of bacteria. Among those, the antibacterial activity of hanburinone, isomoreollin $\mathrm{B}$, morellin, moreollic acid, and morellic acid was tested against MRSA. As a result, moreollic acid and morellic acid displayed significant antibacterial activity with a MIC value of $25 \mu \mathrm{g} / \mathrm{mL}$ while hanburinone, isomoreollin $\mathrm{B}$, and morellin exhibited a relatively modest activity with an equal MIC value of $200 \mu \mathrm{g} / \mathrm{mL}$ (4).

\section{MOLECULAR MECHANISM STUDIES}

It was reported that instead of dealing with the tumor cell directly, these compounds work through a series of biochemical reactions. Among the compounds isolated from G. hanburyi, gambogic acid and gambogenic acid attracted much more interests than the other ones and their potential mechanisms were also well documented in past decades.

\section{Inhibition of Proliferation and Induction of Apoptosis- Related Mechanisms}

The effects of gambogic acid on the growth and apoptosis of osteosarcoma cells were observed in vitro. The result indicated that the inhibition effect of gambogic acid against osteosarcoma cells was found to have a relationship with apoptosis and cell cycle arrest induced by gambogic acid (64). Also, gambogic acid was reported to have an inhibition effect on the catalytic activity of human topoisomerase II $\alpha$ which can reduce the gambogic acid-induced apoptosis and restore cell proliferation and the phosphorylation of c-Jun upon gambogic acid treatment (65). It is reported that gambogenic acid induced A549 cell apoptosis, inhibited the expression of cyclooxygenase (COX-2) and cyclin D1 in messenger RNA (mRNA) level, and arrested the cells to G0/G1 phase in vitro. These results might indicate that gambogenic inhibits cancer cell growth through cell cycle arrest and apoptosis induction (66). Gambogic acid activates $\mathrm{T}$ lymphocytes to induce tumor cell apoptosis. The cDNA microarray analysis revealed that most of the genes that were affected by gambogic acid treatment were immune-related genes (67). Growth inhibition induces the G0/G1 phase cell cycle arrest, and apoptosis could be caused by gambogic acid in human chronic myelogenous leukemia cell line K562 cells. Moreover, 
gambogic acid might show its strong antitumor effects through the interruption of SRC-3 (68). Gambogic acid showed both growth arrest and apoptosis induction effects on Jurkat cells by significantly suppressing the expression of nucleophosmin, which indicated the fact that nucleophosmin and some nucleoporins might serve as new targets of gambogic acid (69). Gambogic acid inhibited tumor cell proliferation by blocking STAT3 activation which associated with proliferation, metastasis, and survival of cancer cells (70). The result of the in vitro research on K562 cells suggests that gambogic acid showed its anti-leukemia effects partially by suppressing the expression level of hERG channel in K562 cells, indicating that gambogic acid can be a promising antitumor agent against leukemia with a mechanism of inhibiting the hERG channel (71).

Among the various signal pathways, the p53 pathway was one of the most important pathways, which is related with apoptosis of cancer cells. Gambogic acid induced apoptosis of tumor cells that expressed wild-type p53 by suppressing MDM2 at both protein and mRNA levels (72). It was confirmed that gambogic acid enhances the p53 protein level through inhibition of MDM2 in p53 wild-type tumor cells. Further study revealed that gambogic acid reduced MDM2 expression in a time-dependent and concentration-dependent way and the inhibition effects were displayed at both posttranslational and transcriptional levels. Moreover, the cytotoxicity, apoptosis, and G2/M cell cycle arrest induced by gambogic acid were found in both p53 wild-type and p53 null tumor cells (73). Gambogic acid was also proved to be a potential inhibitor of the p53-MDM2 interaction via a gene reporter assay in human tumor cells (74). By investigating the relationship between p53 activation and its posttranslational modifications in the human tumor cell lines HepG2 and A549 in response to gambogic acid or adriamycin treatment, it was found that DNA damage response mediated by ATR-Chk1 which is induced by gambogic acid treatment played an important role in $\mathrm{p} 53 / \mathrm{p} 21^{\mathrm{Waf} / \mathrm{CIP} 1}$ activation and downstream G2/ $\mathrm{M}$ arrest (75). It is reported that gambogic acid inhibited cell growth by downregulating the $\mathrm{p} 21^{\text {waf1/cip } 1}$ expression with small interfering RNA which blocked gambogic acid-induced cell differentiation and growth inhibition (76). Additional targets that contribute to its cytotoxic mechanism were reported to be the suppression effect on anti-apoptotic Bcl-2 family proteins induced by gambogic acid, which is indicated by experiments using separated mitochondria in which recombinant purified $\mathrm{Bcl}-2$ family proteins inhibit SMAC release in vitro (77). Gambogic acid can inhibit the growth of A375 cells in a dose-dependent manner and induce their apoptosis, by increasing the $\mathrm{Bax} / \mathrm{Bcl}-2$ ratio and caspase- 3 activity (78). It was reported that gambogic acid induced apoptosis in human MCL JeKo-1 cells via regulating the ratio of Bcl-2/Bax and activating caspase- 3 , caspase- 8 , and caspase- 9 through the mitochondrial pathway (79). Gambogic acid can decrease XIAP expression levels and the ratio of Bcl-2/Bax, which results in inducing HeLa cell apoptosis. During the research, it was also found that gambogic acid seems to bind to the N-terminal ATP-binding domain of Hsp90, which results in the inhibition of heat shock protein 90 (Hsp90) (80). Moreover, human breast cancer cells MCF-7 apoptosis was induced by gambogic acid reducing $\mathrm{Bcl}-2$ expression through p53 (81).
JNK and p38 MAPkinase pathway also play a critical role in cell cycle. Microtubule depolymerization and microtubule cytoskeleton disruption can be caused by gambogic acid in human breast carcinoma MCF-7 cells. Gambogic acid can dramatically increase phosphorylation levels of p38 and cJun N-terminal kinase-1 (JNK-1). Therefore, gambogic acid depolymerized microtubules and increased the phosphorylation levels of p38 and JNK1, which result in G2/M cell cycle arrest and apoptosis in MCF-7 cells (82). It was reported that gambogenic acid induced apoptosis and was related with the Phospho-Erk1/2 and Phospho-p38 MAPK protein expression changes in HepG2 cells (83).

The effect of gambogic on the induction of reactive oxygen species (ROS) accumulation and induction of the mitochondrial signaling pathway was investigated in human hepatoma SMMC-7721 cells. The result indicated that the accumulation of reactive oxygen species (ROS) played an important role in the gambogoc acid-induced mitochondrial signaling pathway, which provided further evidence for the application of gambogic as a promising antitumor agent (84). Further investigation showed the molecular mechanism of ROS toxicity was that the gambogic acid inhibited the TRX-1 and $\mathrm{TRx}-2$ proteins by covalent binding to the active cysteine residues in the functional domain through Michael addition reactions. Because TRX-1 and TRX-2 play critical roles in regulating the redox signaling of cancer cells, the present studies have explained the relationship between protein binding and cellular ROS accumulation triggered by gambogic acid (85). Gambogic acid can induce apoptosis in RPMI8226 cells via ROS accumulation caused by activation of caspase-3, cleavage of PARP, and downregulation of SIRT1 (86).

Moreover, the posttranscriptional regulation effect of the telomerase hTERT induced by gambogic acid was investigated in human gastric carcinoma BGC-823 cells. The result indicated that gambogic acid represses telomerase activity not only by inhibiting hTERT transcriptional activity through c-Myc but also by posttranslational modification of hTERT through Akt (87). Gambogic acid can also induce U87 glioma cell apoptosis via degradation of the epidermal growth factor receptor and inhibition of its downstream Akt/mTORC1 (88).

\section{Inhibition of Invasion and Metastasis-Related Mechanisms}

The cytotoxic effect of gambogic acid was tested against human prostate cancer PC3 cells, whose result showed that gambogic acid inhibits TNF- $\alpha$-induced invasion of PC3 cells through blocking PI3K/Akt and NF- $\mathrm{B}$ signaling pathways (89). The effect on A549 and U251 cells was also tested, and the results showed that gambogic acid and its analogs inhibit the activity of I $\mathrm{kB}$ kinase-beta $(\mathrm{IKK} \beta)$ by blocking the activation of the TNF- $\alpha / N F-\kappa B$ pathway (90). It was reported that reduction of the expression of MMP-2 and MMP-9 was confirmed to be another mechanism of the inhibition activity for cancer metastasis induced by gambogic acid (91). The antiinvasive effect of gambogic acid was investigated in human breast carcinoma cells MDA-MB-231. The result suggests that this effect might be partly because gambogic acid can reduce the expressions of MMP-2 and MMP-9 in MDA-MB-231 (92). It is also reported that gambogic acid reduces the invasiveness 
and metastasis of osteosarcoma cells via suppressing the expression of MMP-9 and upregulating the expression of TIMP1 (93).

\section{DRUG INTERACTIONS}

An interesting research demonstrated that the inhibition of cell viability was dramatically increased when human leukemia K562 and murine hepatocarcinoma H22 cells were treated with the proteasome inhibitor MG262 at different doses and $0.4 \mu \mathrm{M}$ of gambogic acid for $48 \mathrm{~h}$, while using any of them alone could not achieve an identical effect. The result indicated that the combination of gambogic acid and the proteasome inhibitor may result in a synergistic inhibitory effect on the growth of cancer cells (94).

Another study on the inhibitory effects of 5-fluorouracil (5-FU) combined with gambogic acid on BGC-823 human gastric carcinoma cells indicated that the pro-apoptotic activity of the two-drug combination was much stronger than single use (95).

It is reported that gambogic acid can dramatically increase docetaxel sensitivity. The $\mathrm{IC}_{50}$ values of docetaxel against BGC-823 and BGC-823/Doc cells were 0.03 and $1.69 \mu \mathrm{M}$, respectively, indicating that BGC-823/Doc cells were 56.3 times more resistant to docetaxel than parental cells. Gambogic acid can decrease the $\mathrm{IC}_{50}$ of docetaxel to 4-14 times in BGC-823/Doc cells. It was found that gambogic acid at $0.3 \mu \mathrm{M}$ was able to complete reverse docetaxel resistance in BGC-823/Doc cells (96).

The human transferrin receptor (hTfR) is a target for cancer immunotherapy because of its overexpression on the surface of cancer cells. Cytotoxicity was enhanced by combination use of gambogic acid and anti-hTfR IgG3-Av (97).

Proliferation was dramatically inhibited, and the apoptotic rate of Tca8113 cells was significantly improved by combined treatment with gambogic acid and celastrol or the dominant negative mutant SR-I $\kappa \mathrm{B} \alpha$. Therefore, the combination of gambogic acid and celastrol may be a promising method for treating oral squamous cell carcinoma (98).

The inhibitory activity of gambogic acid combined with magnetic nanoparticle of $\mathrm{Fe}_{3} \mathrm{O}_{4}\left(\mathrm{Fe}_{3} \mathrm{O}_{4}\right.$-MNP) on U937 leukemia cells was evaluated, and the result showed that $\mathrm{Fe}_{3} \mathrm{O}_{4}$-MNP can promote gambogic acid-triggered apoptosis in U937 leukemia cells, and the combination of gambogic acid and $\mathrm{Fe}_{3} \mathrm{O}_{4}$-MNP may be a safer treatment for leukemia (99).

Gambogic acid could also inhibit proliferation of LOVO cells and induce apoptosis, which was significantly enhanced by combination use of magnetic nanoparticles containing $\mathrm{Fe}_{3} \mathrm{O}_{4}(100)$.

Gambogic acid treatment can cause the accumulation of monodansylcadaverine (MDC) in autophagic vacuoles, increase expressions of Beclin 1, Atg5, and LC3-II, and increase punctate fluorescent signals in glioblastoma cells pretransfected with GFP-tagged LC3 plasmid. Gambogic acidinduced growth inhibition and apoptotic cell death was enhanced by combination use of autophagy inhibitors and gambogic acid (101).

The effect of gambogic acid in combination with sunitinib (SU), a new multi-targeted oral medication on renal cancer indicated that the combination use of gambogic acid and SU can provide stronger antitumor efficacy compared to either drug alone, which may provide a new clinical treatment strategy for renal cell carcinoma (102).

The combination of gambogic acid and docetaxel can provide synergistic anti-proliferative effects in gastrointestinal cancer cells. Furthermore, gambogic acid dramatically inhibited the mRNA expression of docetaxel-related genes, including tau, $\beta$-tubulinIII, and survivin (103).

It was also found that when gambogic acid and methotrexate were used together, the proportion of cells surviving was lower than that of methotrexate treatment alone (104).

Gambogic acid can also enhance the antitumor activity of doxorubicin on the platinum-resistant human ovarian cancer cell line (SKOV-3) through ROS-induced apoptosis (105).

In another study, the interaction between gambogic acid and chemotherapeutic agents, 5-fluorouracil (5-FU), oxaliplatin (Oxa), and docetaxel (Doc), was investigated. It was found that gambogic acid had a synergistic effect on the cytotoxic activity of chemotherapeutic drugs against human gastric cancer BGC-823 cells and MKN-28 cells. The combination of gambogic acid and chemotherapeutic drugs could also induce apoptosis in a synergistic way. Moreover, gambogic acid was able to downregulate chemotherapeutic agent-associated genes (106).

\section{CONCLUSION}

The caged xanthones from G. hanburyi displayed many potent bioactivities, especially antitumor activity. Analytical and preparative isolation methods also developed along with the process of the research. However, the majority of recent research concentrated on cytotoxicity in vitro and its mechanism. The author thinks that more effort should be put on the research of the in vivo therapy effects and safety. In order to make a further step towards clinical application, we should pay more attention to the shortages of these compounds which hindered their clinical use. To overcome the shortcomings of these xanthones, formulation and structure modification method should be further investigated. Moreover, currently, gambogic acid and gambogenic acid were most studied, so other xanthones should also be concerned for the purpose of finding new drug candidates.

\section{ACKNOWLEDGMENTS}

This study was partly supported by National Key New Drug Discovery Projects (No. 2009ZX09103-399) and Anhui Science and Technology Research Projects (No. 1301042099).

\section{REFERENCES}

1. Anantachoke N, Tuchinda P, Kuhakarn C, Pohmakotr M, Reutrakul V. Prenylated caged xanthones: chemistry and biology. Pharm Biol. 2012;50(1):78-91.

2. Han QB, Xu HX. Caged Garcinia xanthones: development since 1937. Curr Med Chem. 2009;16:3775-96.

3. Deng YX, Pan SL, Zhao SY, Wu MQ, Sun ZQ, Chen XH, et al. Cytotoxic alkoxylated xanthones from the resin of Garcinia hanburyi. Fitoterapia. 2012;83:1548-52. 
4. Sukpondma Y, Rukachaisirikul V, Phongpaichit S. Antibacterial caged-tetraprenylated xanthones from the fruits of Garcinia hanburyi. Chem Pharm Bull. 2005;53(7):850-2.

5. Han QB, Yang L, Wang YL, Qiao CF, Song JZ, Sun DH, et al. A pair of novel cytotoxic polyprenylated xanthone epimers from gamboges. Chem Biodivers. 2006;3:101-5.

6. Han QB, Song JZ, Qiao CF, Wong L, Xu HX. Preparative separation of gambogic acid and its $\mathrm{C}-2$ epimer using recycling high-speed counter-current chromatography. J Chromatogr A. 2006;1127:298-301.

7. Zhou Y, Liu X, Yang J, Han QB, Song JZ, Li SL, et al. Analysis of caged xanthones from the resin of Garcinia hanburyi using ultra-performance liquid chromatography/electrospray ionization quadrupole time-of-flight tandem mass spectrometry. Anal Chim Acta. 2008;629:104-18.

8. Li SL, Song JZ, Han QB, Qiao CF, Xu HX. Improved highperformance liquid chromatographic method for simultaneous determination of 12 cytotoxic caged xanthones in gamboges, a potential anticancer resin from Garcinia hanburyi. Biomed Chromatogr. 2008;22:637-44.

9. Yang J, Ding L, Hu LL, Jin SH, Liu WY, You QD, et al. Rapid characterization of caged xanthones in the resin of Garcinia hanburyi using multiple mass spectrometric scanning modes: the importance of biosynthetic knowledge based prediction. J Pharm Biomed Anal. 2012;60:71-9.

10. Song JZ, Yip YK, Han QB, Qiao CF, Xu HX. Rapid determination of polyprenylated xanthones in gamboge resin of Garcinia hanburyi by HPLC. J Sep Sci. 2007;30:304-9.

11. Ding L, Huang D, Wang JW, Li ST. Determination of gambogic acid in human plasma by liquid chromatography-atmospheric pressure chemical ionization-mass spectrometry. J Chromatogr B. 2007;846:112-8.

12. Tang XY, Zhang P, Ye H, Zhang C, Shen WB, Ping QN. Watersoluble gambogic acid PEGylated prodrugs: synthesis, characterization, physicochemical properties and in vitro hydrolysis. Pharmazie. 2008;63:711-7.

13. Mu R, Lu N, Wang J, Yin YH, Ding Y, Zhang XX, et al. An oxidative analogue of gambogic acid-induced apoptosis of human hepatocellular carcinoma cell line HepG2 is involved in its anticancer activity in vitro. Eur J Cancer Prev. 2010;19:61-7.

14. Wang XJ, Lu N, Yang Q, Dai QS, Tao L, Guo XK, et al. Spectacular modification of gambogic acid on microwave irradiation in methanol: isolation and structure identification of two products with potent anti-tumor activity. Bioorg Med Chem Lett. 2010;20:2438-42.

15. Wang JX, Ma JH, You QD, Zhao L, Wang F, Li C, et al. Studies on chemical modification and biology of a natural product, gambogic acid(II): synthesis and bioevaluation of gambogellic acid and its derivatives from gambogic acid as antitumor agents. Eur J Med Chem. 2010;45:4343-53.

16. Wang JX, Zhao L, Yang H, Guo QL, Zhang L, Wang XJ, et al. Studies on chemical structure modification and biology of a natural product, gambogic acid (I): synthesis and biological evaluation of oxidized analogues of gambogic acid. Eur J Med Chem. 2009;44:2611-20.

17. Zhu X, Zhang C, Wu XL, Tang XY, Ping QN. Preparation, physical properties, and stability of gambogic acid-loaded micelles based on chitosan derivatives. Drug Dev Ind Pharm. 2008;34:2-9.

18. Saxena V, Hussain MD. Poloxamer 407/TPGS mixed micelles for delivery of gambogic acid to breast and multidrug-resistant cancer. Int J Nanomedicine. 2012;7:713-21.

19. Yu F, He CH, Waddad AY, Munyendo WLL, Lv HX, Zhou $\mathrm{JP}$, et al. N-octyl-N-arginine-chitosan (OACS) micelles for gambogic acid oral delivery: preparation, characterization and its study on in situ intestinal perfusion. Drug Dev Ind Pharm. 2014;40(6):774-82.

20. Zhang ZH, Wang XP, Ayman WY, Munyendo WLL, Lv HX, Zhou JP. Studies on lactoferrin nanoparticles of gambogic acid for oral delivery. Drug Deliv. 2013;20(2):86-93.

21. Wang CL, Zhang HJ, Chen BA, Yin HT, Wang WW. Study of the enhanced anticancer efficacy of gambogic acid on Capan-1 pancreatic cancer cells when mediated via magnetic $\mathrm{Fe}_{3} \mathrm{O}_{4}$ nanoparticles. Int J Nanomedicine. 2011;6:1929-35.
22. Wang CL, Zhang HJ, Chen Y, Shi FF, Chen BA. Gambogic acidloaded magnetic $\mathrm{Fe}_{3} \mathrm{O}_{4}$ nanoparticles inhibit Panc-1 pancreatic cancer cell proliferation and migration by inactivating transcription factor ETS1. Int J Nanomedicine. 2012;7:781-7.

23. Hao K, Liu XQ, Wang GJ, Zhao XP. Pharmacokinetics, tissue distribution and excretion of gambogic acid in rats. Eur J Drug Metab Pharmacokinet. 2007;32(2):63-8.

24. Yang J, Ding L, Hu LL, Jin SH, Liu WY, Wang ZZ, et al. Comparison of electron capture-atmospheric pressure chemical ionization and electrospray ionization for the analysis of gambogic acid and its main circulating metabolite in dog plasma. Eur J Mass Spectrom. 2010;16:605-17.

25. Hao K, Zhao XP, Liu XQ, Wang GJ. Determination of gambogic acid in dog plasma by high-performance liquid chromatography for a pharmacokinetic study. Biomed Chromatogr. 2007;21:279-83.

26. Feng F, Liu WY, Wang YH, Guo QL, You QD. Structure elucidation of metabolites of gambogic acid in vivo in rat bile by high-performance liquid chromatography-mass spectrometry and high-performance liquid chromatography-nuclear magnetic resonance. J Chromatogr B. 2007;860:218-26.

27. Yang J, Ding L, Hu LL, Qian WJ, Jin SH, Sun XP, et al. Metabolism of gambogic acid in rats: a rare intestinal metabolic pathway responsible for its final disposition. Drug Metab Dispos. 2011;39:617-26.

28. Huang X, Chen YJ, Peng DY, Li QL, Wang XS, Wang DL, et al. Solid lipid nanoparticles as delivery systems for gambogenic acid. Colloids Surf B. 2013;102:391-7.

29. Liu YT, Hao K, Liu XQ, Wang GJ. Metabolism and metabolic inhibition of gambogic acid in rat liver microsomes. Acta Pharmacol Sin. 2006;27(9):1253-8.

30. Qiang L, Yang Y, You QD, Ma YJ, Yang L, Nie FF, et al. Inhibition of glioblastoma growth and angiogenesis by gambogic acid: an in vitro and in vivo study. Biochem Pharmacol. 2008;75:1083-92.

31. Zhao J, Qi Q, Yang Y, Gu HY, Lu N, Liu W, et al. Inhibition of $\alpha_{4}$ integrin mediated adhesion was involved in the reduction of B16-F10 melanoma cells lung colonization in C57BL/6 mice treated with gambogic acid. Eur J Pharmacol. 2008;589:127-31.

32. Li CL, Qi Q, Lu N, Dai QS, Li FN, Wang XT, et al. Gambogic acid promotes apoptosis and resistance to metastatic potential in MDA-MB-231 human breast carcinoma cells. Biochem Cell Biol. 2012;90:718-30.

33. Guo QL, You QD, Wu ZQ, Yuan ST, Zhao L. General gambogic acids inhibited growth of human hepatoma SMMC7721 cells in vitro and in nude mice. Acta Pharmacol Sin. 2004;25(6):769-74.

34. Lu N, Yang Y, You QD, Ling Y, Guo Y, Gu HY, et al. Gambogic acid inhibits angiogenesis through suppressing vascular endothelial growth factor-induced tyrosine phosphorylation of KDR/ Flk-1. Cancer Lett. 2007;258:80-9.

35. Yi TF, Yi ZF, Cho SG, Luo J, Pandey MK, Aggarwal BB, et al. Gambogic acid inhibits angiogenesis and prostate tumor growth by suppressing vascular endothelial growth factor receptor 2 signaling. Cancer Res. 2008;68:1843-50.

36. Lu N, Hui $\mathrm{H}$, Yang $\mathrm{H}$, Zhao $\mathrm{K}$, Chen $\mathrm{Y}$, You QD, et al. Gambogic acid inhibits angiogenesis through inhibiting PHD2VHL-HIF-1 $\alpha$ pathway. Eur J Pharm Sci. 2013;49(2):220-6.

37. Guo QL, Qi Q, You QD, Gu HY, Zhao L, Wu ZQ. Toxicological studies of gambogic acid and its potential targets in experimental animals. Basic Clin Pharmacol Toxicol. 2006;99:178-84.

38. Qi Q, You QD, Gu HY, Zhao L, Liu W, Lu N, et al. Studies on the toxicity of gambogic acid in rats. J Ethnopharmacol. 2008;117:433-8.

39. Zhao L, Zhen C, Wu ZQ, Hu R, Zhou CL, Guo QL. General pharmacological properties, developmental toxicity, and analgesic activity of gambogic acid, a novel natural anticancer agent. Drug Chem Toxicol. 2010;33(1):88-96.

40. Han QB, Wang YL, Yang L, Tso TF, Qiao CF, Song JZ, et al. Cytotoxic polyprenylated xanthones from the resin of Garcinia hanburyi. Chem Pharm Bull. 2006;54(2):265-7.

41. Hahnvajanawong C, Boonyanugomol W, Nasomyon T, Loilome W, Namwat N, Anantachoke N, et al. Apoptotic 
activity of caged xanthones from Garcinia hanburyi in cholangiocarcinoma cell lines. World J Gastroenterol. 2010;16(18):2235-43.

42. Lee RNH, Ho WS. Antiproliferative activity of gambogic acid isolated from Garcinia hanburyi in Hep3B and Huh7 cancer cells. Oncol Rep. 2013;29:1744-50.

43. Rahman MA, Kim NH, Huh SO. Cytotoxic effect of gambogic acid on SH-SY5Y neuroblastoma cells is mediated by intrinsic caspase-dependent signaling pathway. Mol Cell Biochem. 2013;377:187-96.

44. Tao SJ, Wang Y, Zhang X, Guan SH, Guo DA. Biotransformation of gambogenic acid by Chaetomium globosum CICC 2445. Nat Prod Commun. 2012;7(2):197-8.

45. Tao SJ, Guan SH, Wang W, Lu ZQ, Chen GT, Sha N, et al. Cytotoxic polyprenylated xanthones from the resin of Garcinia hanburyi. J Nat Prod. 2009;72:117-24.

46. Hahnvajanawong C, Ketnimit S, Pattanapanyasat K, Anantachoke N, Sripa B, Pinmai K, et al. Involvement of p53 and nuclear factor-kappa B signaling pathway for the induction of G1-phase cell cycle arrest of cholangiocarcinoma cell lines by isomorellin. Biol Pharm Bull. 2012;35(11):1914-25.

47. Guo QL, Lin SS, You QD, Gu HY, Yu J, Zhao L, et al. Inhibition of human telomerase reverse transcriptase gene expression by gambogic acid in human hepatoma SMMC-7721 cells. Life Sci. 2006;78:1238-45.

48. Yang Y, Yang L, You QD, Nie FF, Gu HY, Zhao L, et al. Differential apoptotic induction of gambogic acid, a novel anticancer natural product, on hepatoma cells and normal hepatocytes. Cancer Lett. 2007;256:259-66.

49. Wang Y, Chen Y, Chen Z, Wu Q, Ke WJ, Wu QL. Gambogic acid induces death inducer-obliterator 1-mediated apoptosis in Jurkat T cells. Acta Pharmacol Sin. 2008;29(3):349-54.

50. Wang X, Chen YC, Han QB, Chan CY, Wang H, Liu Z, et al. Proteomic identification of molecular targets of gambogic acid: role of stathmin in hepatocellular carcinoma. Proteomics. 2009;9:242-53.

51. Zhao L, Guo QL, You QD, Wu ZQ, Gu HY. Gambogic acid induces apoptosis and regulates expressions of Bax and Bcl-2 protein in human gastric carcinoma MGC-803 cells. Biol Pharm Bull. 2004;27(7):998-1003.

52. Wu ZQ, Guo QL, You QD, Zhao L, Gu HY. Gambogic acid inhibits proliferation of human lung carcinoma SPC-A1 cells in vivo and in vitro and represses telomerase activity and telomerase reverse transcriptase mRNA expression in the cells. Biol Pharm Bull. 2004;27(11):1769-74.

53. Liu W, Guo QL, You QD, Zhao L, Gu HY, Yuan ST. Anticancer effect and apoptosis induction of gambogic acid in human gastric cancer line BGC-823. World J Gastroenterol. 2005;11(24):36559.

54. Yu J, Guo QL, You QD, Zhao L, Gu HY, Yang Y, et al. Gambogic acid-induced $\mathrm{G} 2 / \mathrm{M}$ phase cell-cycle arrest via disturbing CDK7-mediated phosphorylation of $\mathrm{CDC} 2 / \mathrm{p} 34$ in human gastric carcinoma BGC-823 cells. Carcinogenesis. 2007;28(3):632-8.

55. Kasibhatla S, Jessen KA, Maliartchouk S, Wang JY, English NM, Drewe J, et al. A role for transferrin receptor in triggering apoptosis when targeted with gambogic acid. Proc Natl Acad Sci. 2005;102(3):12095-100.

56. Tao ZJ, Zhou YL, Lu JJ, Duan WH, Qin YX, He XX, et al. Caspase-8 preferentially senses the apoptosis-inducing action of NG-18, a gambogic acid derivative, in human leukemia HL-60 cells. Cancer Biol Ther. 2007;6(5):691-6.

57. Han QB, Cheung S, Tai J, Qiao CF, Song JZ, Hong XX. Stability and cytotoxicity of gambogic acid and its derivative, gambogoic acid. Biol Pharm Bull. 2005;28(12):2335-7.

58. Han QB, Yang L, Liu Y, Wang YL, Qiao CF, Song JZ, et al. Gambogic acid and epigambogic acid, C2-epimers with novel anticancer effects of Garcinia hanburyi. Planta Med. 2006;72:281-4.

59. Yu J, Guo QL, You QD, Lin SS, Li Z, Gu HY, et al. Repression of telomerase reverse transcriptase mRNA and hTERT promoter by gambogic acid in human gastric carcinoma cells. Cancer Chemother Pharmacol. 2006;58:434-43.

60. Shu WX, Chen Y, He J, Cui GH. Effects of gambogic acid on the regulation of nucleoporin Nup88 in U937 cells. J Huazhong Univ Sci Technolog. 2007;27(4):388-92.
61. Reutrakul V, Anantachoke N, Pohmakotr M, Jaipetch T, Yoosook C, Kasisit J, et al. Anti-HIV-1 and anti-inflammatory lupanes from the leaves, twigs, and resin of Garcinia hanburyi. Planta Med. 2010;76:368-71.

62. Reutrakul V, Anantachoke N, Pohmakotr M, Jaipetch T, Sophasan C, Yoosook C, et al. Cytotoxic and anti-HIV-1 caged xanthones from the resin and fruit of Garcinia hanburyi. Planta Med. 2007;73:33-40.

63. Jang SW, Okada M, Sayeed L, Xiao G, Stein D, Jin P, et al. Gambogic amide, a selective agonist for TrkA receptor that possesses robust neurotrophic activity, prevents neuronal cell death. Proc Natl Acad Sci. 2007;104(41):16329-34.

64. Zhao W, Zhou SF, Zhang ZP, Xu GP, Li XB, Yan JL. Gambogic acid inhibits the growth of osteosarcoma in vitro by inducing apoptosis and cell cycle arrest cells. Oncol Rep. 2011;25:1289-95.

65. Qin YX, Meng LH, Hu CX, Duan WH, Zuo ZL, Lin LP, et al. Gambogic acid inhibits the catalytic activity of human topoisomerase II $\alpha$ by binding to its ATPase domain. Mol Cancer Ther. 2007;6:2429-40.

66. Li QL, Cheng H, Zhu GQ, Yang L, Zhou A, Wang XS, et al. Gambogenic acid inhibits proliferation of A549 cells through apoptosis-inducing and cell cycle arresting. Biol Pharm Bull. 2010;33(3):415-20.

67. Gu HY, You QD, Liu W, Yang Y, Zhao L, Qi Q, et al. Gambogic acid induced tumor cell apoptosis by $\mathrm{T}$ lymphocyte activation in $\mathrm{H}_{22}$ transplanted mice. Int Immunopharmacol. 2008;8:1493-502.

68. Li R, Chen Y, Zeng LL, Shu WX, Zhao F, Wen L, et al. Gambogic acid induces G0/G1 arrest and apoptosis involving inhibition of SRC-3 and inactivation of Akt pathway in K562 leukemia cells. Toxicology. 2009;262:98-105.

69. Shu WX, Chen Y, Li R, Wu Q, Cui GH, Ke WJ, et al. Involvement of regulations of nucleophosmin and nucleoporins in gambogic acid-induced apoptosis in Jurkat cells. Basic Clin Pharmacol Toxicol. 2008;103:530-7.

70. Prasad S, Pandey MK, Yadav VR, Aggarwal BB. Gambogic acid inhibits STAT3 phosphorylation through activation of protein tyrosine phosphatase SHP-1:potential role in proliferation and apoptosis. Cancer Prev Res. 2011;4(7):1084-94.

71. Cui GH, Shu WX, Wu Q, Chen Y. Effect of gambogic acid on the regulation of hERG channel in K562 cells in vitro. J Huazhong Univ Sci Technol. 2009;29(5):540-5.

72. Gu HY, Wang XT, Rao SY, Wang J, Zhao J, Ren FL, et al. Gambogic acid mediates apoptosis as a p53 inducer through down-regulation of $\mathrm{mdm} 2$ in wild-type p53-expressing cancer cells. Mol Cancer Ther. 2008; 7:3298-305.

73. Rong JJ, Hu R, Qi Q, Gu HY, Zhao Q, Wang J, et al. Gambogic acid down-regulates MDM2 oncogene and induces p21 Waf1/CIP1 expression independent of p53. Cancer Lett. 2009;284:102-12.

74. Leao M, Gomes S, Chaverri JP, Machado N, Sousa E, Pinto M, et al. $\alpha$-Mangostin and gambogic acid as potential inhibitors of the p53-MDM2 interaction revealed by a yeast approach. J Nat Prod. 2013;76:774-8.

75. Rong JJ, Hu R, Song XM, Ha J, Lu N, Qi Q, et al. Gambogic acid triggers DNA damage signaling that induces p53/p21 Waf1/ ${ }_{\mathrm{CIP} 1}$ activation through the ATR-Chk1 pathway. Cancer Lett. 2010;296:55-64.

76. Chen Y, Hui H, Li Z, Wang HM, You QD, Lu N. Gambogic acid induces growth inhibition and differentiation via up regulation of $21^{\text {waf1/cip } 1}$ expression in acute myeloid leukemia cells. J Asian Nat Prod Res. 2014;16(10):1000-8.

77. Zhai DY, Jin CF, Shiau CW, Kitada S, Satterthwait AC, Reed JC. Gambogic acid is an antagonist of antiapoptotic Bcl-2 family proteins. Mol Cancer Ther. 2008;7:1639-46.

78. Xu XY, Liu YQ, Wang L, He J, Zhang HF, Chen XX, et al. Gambogic acid induces apoptosis by regulating the expression of Bax and Bcl-2 and enhancing caspase- 3 activity in human malignant melanoma A375 cells. Int J Dermatol. 2009;48:186-92.

79. Xu JY, Zhou M, Ouyang J, Wang J, Zhang QG, Xu Y, et al. Gambogic acid induces mitochondria-dependent apoptosis by modulation of Bcl-2 and Bax in mantle cell lymphoma JeKo-1 cells. Chin J Cancer Res. 2013;25(2):183-91.

80. Zhang LR, Yi YT, Chen JJ, Sun YF, Guo QJ, Zhang ZH, et al. Gambogic acid inhibits Hsp90 and deregulates TNF-a/NF-kB in HeLa cells. Biochem Biophys Res Commun. 2010;403:282-7. 
81. Gu HY, Rao SY, Zhao J, Wang J, Mu R, Rong JJ, et al. Gambogic acid reduced bcl-2 expression via p53 in human breast MCF-7 cancer cells. J Cancer Res Clin Oncol. 2009;135:1777-82.

82. Chen J, Gu HYLN, Yang Y, Liu W, Qi Q, et al. Microtubule depolymerization and phosphorylation of c-Jun N-terminal kinase-1 and p38 were involved in gambogic acid induced cell cycle arrest and apoptosis in human breast carcinoma MCF-7 cells. Life Sci. 2008;83:103-9.

83. Yan FG, Wang M, Li JM, Cheng H, Su JJ, Wang XS, et al. Gambogenic acid induced mitochondrial-dependent apoptosis and referred to Phospho-Erk1/2 and Phospho-p38 MAPK in human hepatoma HepG2 cells. Environ Toxicol Pharmacol. 2012;33:181-90.

84. Nie FF, Zhang XN, Qi Q, Yang L, Yang Y, Liu W, et al. Reactive oxygen species accumulation contributes to gambogic acidinduced apoptosis in human hepatoma SMMC-7721 cells. Toxicol. 2009;260:60-7.

85. Yang J, Li CL, Ding L, Guo QL, You QD, Jin SH. Gambogic acid deactivates cytosolic and mitochondrial thioredoxins by covalent binding to the functional domain. J Nat Prod. 2012;75:1108-16.

86. Yang LJ, Chen Y, He J, Yi S, Wen L, Zhao SA, et al. Effects of gambogic acid on the activation of caspase-3 and downregulation of SIRT1 in RPMI-8226 multiple myeloma cells via the accumulation of ROS. Oncol Lett. 2012;3:1159-65.

87. Zhao Q, Yang Y, Yu J, You QD, Zeng S, Gu HY, et al. Posttranscriptional regulation of the telomerase hTERT by gambogic acid in human gastric carcinoma 823 cells. Cancer Lett. 2008;262:223-31.

88. He XY, Liu XJ, Chen X, Bian LG, Zhao WG, Shen JK, et al. Gambogic acid induces EGFR degradation and Akt/mTORC1 inhibition through AMPK dependent-LRIG1 upregulation in cultured U87 glioma cells. Biochem Biophys Res Commun. 2013:435(3):397-402.

89. Lü L, Tang D, Wang L, Huang LQ, Jiang GS, Xiao XY, et al. Gambogic acid inhibits TNF- $\alpha$-induced invasion of human prostate cancer PC3 cells in vitro through PI3K/Akt and NF-kB signaling pathways. Acta Pharmacol Sin. 2012;33:531-41.

90. Sun HP, Chen FH, Wang XJ, Liu ZL, Yang Q, Zhang XJ, et al. Studies on gambogic acid (IV): Exploring structure activity

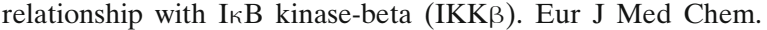
2012;51:110-23.

91. Qi Q, Gu HY, Yang Y, Lu N, Zhao J, Liu W, et al. Involvement of matrix metalloproteinase 2 and 9 in gambogic acid induced suppression of MDA-MB-435 human breast carcinoma cell lung metastasis. J Mol Med. 2008;86:1367-77.

92. Qi Q, Lu N, Wang XT, Gu HY, Yang Y, Liu W, et al. Antiinvasive effect of gambogic acid in MDA-MB-231 human breast carcinoma cells. Biochem Cell Biol. 2008;86:386-95.

93. Xin ZF, Shen CC, Tao LJ, Yan SG, Wu HB. Gambogic acid inhibits invasion of osteosarcoma via upregulation of TIMP-1. Int J Mol Med. 2013;31:105-12.
94. Huang HB, Chen D, Li SJ, Li XF, Liu NN, Lu XY, et al. Gambogic acid enhances proteasome inhibitor-induced anticancer activity. Cancer Lett. 2011;301:221-8.

95. Wang J, Liu W, Zhao Q, Qi Q, Lu N, Yang Y, et al. Synergistic effect of 5-fluorouracil with gambogic acid onBGC-823 human gastric carcinoma. Toxicology. 2009;256:135-40.

96. Wang TT, Wei J, Qian XP, Ding YT, Yu LX, Liu BR. Gambogic acid, a potent inhibitor of survivin, reverses docetaxel resistance in gastric cancer cells. Cancer Lett. 2008;262:214-22.

97. Sanchez EO, Daniels TR, Helguera G, Maza OM, Bonavida B, Penichet ML. Enhanced cytotoxicity of an anti-transferrin receptor IgG3-avidin fusion protein in combination with gambogic acid against human malignant hematopoietic cells: functional relevance of iron, the receptor, and reactive oxygen species. Leukemia. 2009;23:59-70.

98. He D, Xu Q, Yan M, Zhang P, Zhou XJ, Zhang ZY, et al. The NF-kappa B inhibitor, celastrol, could enhance the anti-cancer effect of gambogic acid on oral squamous cell carcinoma. BioMed Cent Cancer. 2009;9:343-52.

99. Liang YQ, Chen BA, Wu WW, Gao F, Xia GH, Shao ZY, et al. Effects of magnetic nanoparticle of $\mathrm{Fe}_{3} \mathrm{O}_{4}$ on apoptosis induced by gambogic acid in U937 leukemia cells. J Exp Hematol. 2010;18(1):67-73.

100. Fang LH, Chen BA, Liu SL, Wang RP, Hu SY, Xia GH, et al. Synergistic effect of a combination of nanoparticulate $\mathrm{Fe}_{3} \mathrm{O}_{4}$ and gambogic acid on phosphatidylinositol 3-kinase/ Akt/Bad pathway of LOVO cells. Int J Nanomedicine. 2012;7:4109-18.

101. Luo GX, Cai J, Lin JZ, Luo WS, Luo HS, Jiang YY, et al. Autophagy inhibition promotes gambogic acid-induced suppression of growth and apoptosis in glioblastoma cells. Asian Pac J Cancer Prev. 2012;13(12):6211-6.

102. Jiang XL, Zhang Y, Luo CL, Wu XH. Targeting renal cell carcinoma with gambogic acid in combination with sunitinib in vitro and in vivo. Asian Pac J Cancer Prev. 2012;13(12):6463-8.

103. Zou ZJ, Xie L, Wei J, Yu LX, Qian XP, Chen JH, et al. Synergistic anti-proliferative effects of gambogic acid with docetaxel in gastrointestinal cancer cell lines. BioMed Cent Complement Alternat Med. 2012;12:58-67.

104. Deschatrette J, Bonaventure KN, Philippe L, Wolfrom C. Interaction between gambogic acid and dihydrofolate reductase and synergistic lethal effects with methotrexate on hepatoma cells. Anticancer Res. 2013;33:133-42.

105. Wang JX, Yuan ZX. Gambogic acid sensitizes ovarian cancer cells to doxorubicin through ROS-mediated apoptosis. Cell Biochem Biophys. 2009;13:9534-7.

106. Zou ZJ, Wei J, Li XL, Yu LX, Wang TT, Qian XP, et al. Enhancement of anticancer efficacy of chemotherapeutics by gambogic acid against gastric cancer cells. Cancer Biother Radiopharm. 2012;27(5):299-306. 